
\title{
3 Researchspluare \\ Role of Differentially Expressed Proteins in Acquired Resistance to Cdk4/6 Inhibitor in Breast Cancer
}

\section{Binayak Kumar}

National Institute of Cancer Prevention and Research

Peeyush Prasad

SGRH: Sir Ganga Ram Hospital

\section{Ragini Singh}

National Institute of Cancer Prevention and Research

\section{Ram Krishana Sahu}

National Institute of Cancer Prevention and Research

\section{Ashutosh Singh}

Shiv Nadar University

\section{Srikrishna Jayadev M}

Shiv Nadar University

\section{Suresh Hedau ( $\nabla$ suresh.hedau@gov.in )}

Institute of Cytology and Preventive Oncology: National Institute of Cancer Prevention and Research https://orcid.org/0000-0002-9576-1341

\section{Research Article}

Keywords: Drug-resistance, Breast Cancer, Apoptosis, Cell-cycle, and Proteome.

Posted Date: May 27th, 2021

DOl: https://doi.org/10.21203/rs.3.rs-556331/v1

License: (c) (i) This work is licensed under a Creative Commons Attribution 4.0 International License. Read Full License 


\section{Abstract}

$\mathrm{CDK} 4 / 6$ inhibitors (Abemaciclib, Ab and Palbociclib, Pb) stop the G1-phase in cell-cycle being used to cure advanced stage of breast cancer (BC). Acquired resistance is a major challenge in BC therapy. The molecular signature of the therapy resistance for $\mathrm{Ab}$ and $\mathrm{Pb}$ drugs in $\mathrm{BC}$ should be explored. Here, we developed $\mathrm{Ab} / \mathrm{Pb}$-resistant cell-models and explored the molecular changes. Drug's resistance cells were developed in MCF-7 cells by continuous drug treatment and it was confirmed by MTT-assay, PI-stainingmicroscopy, and real-time-qPCR. Global proteome profiling done by Labelled-free-Proteome-OrbitrapFusion-MS-MS technique. Bioinformatics tools used to analyse the proteome data. Ab-resistant and Pbresistant MCF-7 cells showed increased tolerance for the respective drug. The BCL-2 and MCL-1 survival genes were up-regulated, while the apoptosis genes BAD, BAX, CASP-3 and PARP-1 were down-regulated in the resistant cells. Expression of the MDR-1, ABCG2, ESR-1, CDK4, CDK6, and Cyclin-D1 genes were increased in both resistance cells. For proteomics, 237 and 239 proteins were expressed differently in the resistant $A b$ and Pb cells, respectively. The NUDT5, PEPD, ABAT, ATP1B1, GGCT, and SELENBP1 proteins were down-regulated and the SBSN, HSD17B10, CD9, PDIA3, PSMB4, SLC2A1, and VTN proteins were upregulated in Ab-resistant cells. The NUDT5, PEPD, and GGCT proteins were down-regulated, while CD47, HIST1H2BN, LMNA, VTN, PSMB5, HBB, PSMA7, FLNB, PRDX4, VDAC1, GOT2, HSPA5, SERPINH1, EIF4A2, $\mathrm{FTH}$, and VIM proteins were up-regulated in Pb-resistant cells. These proteins are a new set of prognostic markers and drug targets for overcoming the respective drug resistance. However, it is necessary to perform an in vivo or clinical assessment.

\section{Introduction}

Breast cancer is the second most commonly diagnosed cancer in the world, after lung cancer; however, it is the most prevalent in the Indian population [1-3]. Breast cancers are classified by the presence or absence of a surface receptor, that is, the estrogen receptor (ER), the progesterone receptor (RP), and the human epidermal growth factor receptor 2 (HER-2). Radiotherapy, chemotherapy, hormone therapy, and targeted therapy are all common treatment methods [4]. To treat primary and metastatic breast cancer, chemotherapy drugs such as 5-fluorouracil, methotrexate, cyclophosphamide, doxorubicin, and epirubicin are used. [5, 6].ER inhibitors (tamoxifen, letrozole, and fulvestrant) are used to treat estrogen-positive breast cancer in hormone therapy. Tumor cells develop tolerance to drug cytotoxicity, resulting in the therapeutic resistance phenotype, which contributes to disease progression and recurrence. $[5,6]$. Tumor cells triggered other pathways essential for their survival in the process of acquiring the resistance trait [5, 6].The investigation of the molecular mechanisms underlying therapeutic resistance in cancer care has resulted in a transition in drug development toward targeted therapy.By inhibiting certain proteins necessary for tumor cell proliferation and survival, targeted therapy prevents cancer progression. Proteins such as receptor tyrosine kinase, cytokine receptors, and intracellular serine-threonine kinases can be targeted.

Abemaciclib (Ab) and Palbociclib (Pb) are two synthetic (small-molecule) inhibitors of cyclin-dependent kinase 4 and 6 (CDK4 and CDK6) [7]. CDK 4 and 6 are intracellular, serine-threonine protein kinase 
enzyme associated with cell-cycle progression from G1 to S-phase. Inhibition of CDK4 and CDK6 will halt the $\mathrm{G} 1$ phase of the cells. The U.S. FDA approved Palbociclib in 2016, while Abemaciclib approved in 2017 to treat advanced breast cancer with ER, PR positive and HER2-negative receptors $[8,9]$. Deregulation of CDK4/6 causes uncontrolled cell proliferation, which may occur due to amplification of cyclin D1, a gain of CDK4/6, loss of p18, elevated Rb1, and loss of p16, etc. [10-13]. CDK4/6 inhibitors have emerged as breakthrough for breast cancer treatment. Recently, resistance to CDK4/6 inhibitors has been identified as a concern in the management of breast cancer [14-16]. PI3K-AKT-mTOR signal mediated resistance to CDK4/6 inhibitors is reported for a similar medicine ribociclib. [17]. However, resistance mechanisms for $\mathrm{Ab}$ and $\mathrm{Pb}$ drugs in breast cancer therapy have not been reported.

This study aims to develop drug-resistant cell models for the drugs Abemaciclib and Palbociclib in the breast cancer cell lineage and further assess the molecular changes involved in resistance.

\section{Materials And Methods}

Abemaciclib and Palbociclib drugs were purchased from Selleck Chem, USA. MCF-7 was bought from NCCS Pune in India. Cell culture media (Lonza), FBS (Gibco life technology), Plastic-wares for cell-culture (Corning), 96-well plate for real-time-qPCR of Thermo Scientific, RNA isolation kit (Qiagen), cDNA synthesis kit (Takara), 2x SYBR Green-Master mix (Promega) and Primers synthesized from Imperial Life Sciences Pvt. Ltd. Both, control and resistant cells were maintained in high glucose DMEM medium supplemented with 10\% FBS and 1\% Penicillin and streptomycin antibiotics in 5\% CO2, humidified air and at $37 \mathrm{OC}$ temperature. To develop resistance models, MCF-7 cells were treated with Abemaciclib and Palbociclib drugs in separate T-25 flasks at initial $5 \mathrm{~nm}$ concentrations. The drug doses were gradually increased up to $200 \mathrm{~nm}$ concentrations and keep maintaining cells at the same.

\section{Cell-viability Assay}

MCF-7 and continued drug-treated cells called Ab-R-MCF-7 and Pb-R-MCF-7 with Ab and Pb drug, respectively, are seeded in a 96-well plate with $2.5 \times 10^{4}$ cells count in each well. After $24 \mathrm{~h}$ of incubation, cells were treated with the respective drug from $100 \mathrm{~nm}$ to $6 \mu \mathrm{M}$ concentrations in drug-sensitive MCF-7 cells and up to $8 \mu \mathrm{M}$ for drug-resistant MCF-7 cells for 48 and $72 \mathrm{~h}$. Add $100 \mu \mathrm{l}$ of $0.5 \mu \mathrm{g} / \mu \mathrm{l} \mathrm{MTT}$ to each well and incubated for $2.5 \mathrm{~h}$ than lysed the cells with detergent (DMSO). OD-value was measured at 595 $\mathrm{nm}$ wavelength into micro-plate reader and percent cell viability was calculated.

\section{PI-Staining-microscopy}

MCF-7, Ab-R-MCF-7, and Pb-R-MCF-7 cells were seeded ( $4 \times 10^{4}$ cells/well) in a 12-well plate and incubated into a $\mathrm{CO} 2$ incubator for $24 \mathrm{hrs}$. Cells were treated with $\mathrm{Ab}$ and $\mathrm{Pb}$ of 1.5 and $2.0 \mu \mathrm{M}$ concentrations for 48 and $72 \mathrm{~h}$, respectively. Cells were stained with $25 \mu \mathrm{g} / \mathrm{ml}$ propidium iodide (PI) for $15 \mathrm{~min}$. Pl-stained cells exposed to green mono-chromatic light and red-emission light were captured along with white light. Images were taken on 20x magnification into a Nikon inverted fluorescence microscope. 


\section{Real-TimeqPCR}

MCF-7, Ab-R-MCF-7, and Pb-R-MCF-7 cells were seeded (7.5x104 cells/well) into 6-well plates and incubated into $\mathrm{CO} 2$ incubator for $24 \mathrm{hrs}$. Cells were treated with $\mathrm{Ab}(0.25 \mu \mathrm{M})$ and $\mathrm{Pb}(2.0 \mu \mathrm{M})$ drugs for $48 \mathrm{~h}$. Cells detached and washed with cold PBS. Total RNA is extracted from cells palette using total RNA isolation kit followed the kit protocols. The quantity and quality of total RNA was measured by NanoDrop. $0.5 \mu \mathrm{g}$ total RNA is used for cDNA synthesis following the protocols mentioned in cDNA synthesis kit. Real-time-qPCR was performed in triplicate using Bio-Red connect real-time-qPCR system using the $2 X$ Master mix of SYBR Green (from Promega) and gene-specific primers.18S gene was selected as an internal control for normalization. Relative quantity (RQ) - value for each gene were analyzed for each sample from their Ct-value. The list of genes and primer sequences is listed in Supplemental Table 1.

\section{Labelle free-Proteome-Orbitrap-Fusion MS-MS}

Samples were prepared for a proteomics experiment for MCF-7 control, Ab-R-MCF-7 and Pb-R-MCF-7 cells. Cells were seeded $\left(7.5 \times 10^{4}\right.$ cells/well) in T-25 flasks, incubated in a $\mathrm{CO}_{2}$ incubator for $48 \mathrm{~h}$, after those cells were harvested and lysed in a cell lysis buffer ( $6 \mathrm{M}$ urea, $2 \mathrm{M}$ thiourea, $2 \%$ CHAPS and $0.5 \%$ SDS) containing $1 \%$ protease inhibitor cocktail. Cell samples were sonicated on ice for 30 sec pulse with 10 sec gaps for 5 times, centrifuged the cell-lysate at $12000 \mathrm{rpm}$ for $15 \mathrm{~min}$ at $4^{0} \mathrm{C}$ than supernatant was collected. Proteins were estimated using Bradford reagent (Sigma) and measured the OD value in the microplate reader at $595 \mathrm{~nm}$ wavelength light exposed. Protein quality was checked by Coomassie blue after running SDS-PAGE. Protein samples were sent to the proteomics laboratory, MASSFIITB facility supported by DBT (BT/PR13114/INF/22/206/2015), IIT Bombay, Mumbai. The technique was used for proteomics is labelled free-Proteome- Orbitrap-Fusion MS-MS. The protein search is performed against the Homo sapiens database downloaded from UniProt using Proteome Discoverer 2.2.

\section{Bioinformatics}

Bioinformatics tools were used to analyse proteomics data. Venny tool used to select common proteins in replicating data. The reactome pathway database was used to find the role of proteins in different reaction pathways. Gene Ontology (GO) analysis was performed using the STRING database. A network analyst tool used to find the proteins hub. Generic PPI was analysed without any filter, but the subnetwork having maximum seed. miR-Net tool used for miRNA-Gene interaction analysis to explore the posttranscriptional regulation of gene expressions. Here, identified protein IDs were searched against the background of breast cancer tissues. The minimum network option was selected for the analysis.

\section{Results}

\section{Increased tolerance to Abemaciclib and Palbociclib in Ab-R- MCF-7 and Pb-R-MCF-7 cells}


MCF-7 cells were treated with Abemaciclib and Palbociclib and the inhibitory concentration values were calculated. Cells treated with Ab exhibited an IC50 value of $1.5 \mu \mathrm{M}$ at $48 \mathrm{~h}$ and cells treated with $\mathrm{Pb}$ showed an IC50 $3.0 \mu \mathrm{M}$ after $72 \mathrm{~h}$. These sensitive MCF-7 cells were treated continuously with an increasing concentration ranging from 0.1 to $8 \mu \mathrm{M}$. As shown in Figure-1 cytotoxicity was assessed in the continuously drug-exposed cells and it was found that Ab treated cells could tolerate the drug up to a concentration of $7.0 \mu \mathrm{M}$ after $48 \mathrm{hrs}$ and the $\mathrm{Pb}$ treated cells could tolerate up to $7.5 \mu \mathrm{M}$ after $72 \mathrm{~h}$. When increased IC50 values were compared to the sensitive cells could survive higher drug concentration, indicating that these cells develop resistance to the drugs.

\section{Reduced Cell Death In Drug-resistant Cells}

Further to reconfirm the cytotoxicity results obtained in the above experiments Propidium lodide exclusion experiment was performed. Control-sensitive-cells and the $\mathrm{Ab}$ and $\mathrm{Pb}$-resistant MCF-7 cells were treated with the respective drug for $48 \mathrm{~h}$, and stained with propidium iodide. Control-MCF-7 cells without any drug treatment looked healthy and, few cells stained red with PI, whereas the MCF-7 cells treated with $\mathrm{Ab}$ and $\mathrm{Pb}$ exhibited stressed phenotype and a great number of cells picked-up Pl-stain. However, only a few drugresistant cells picked up PI stain and the rest of the cells looked healthier (Fig. 1. C, D, E). Again, confirming the tolerance of the resistant cells to these drugs.

\section{Up-regulation Of Pro-survival And Down-regulation Of Apoptotic Genes}

To check the cell death at the mRNA level the expression of pro-survival and apoptosis-associated genes were checked. qPCR results as shown in Fig. 2B, the expression of pro-survival genes BCL-2 and MCL-1 were found to be up-regulated in resistant cells. BCL-2 expression was enhanced by 3.13 and 1.60 -fold in Ab-RMCF-7 and Pb-R-MCF-7 cells, respectively, whereas, MCL-1 were 4.90 and 5.80-fold higher expression in Ab-R-MCF-7 and Pb-R-MCF-7 respectively as compare to the control. Pro-apoptotic genes BAX, BAD, Casp-3 and PARP1 expressions in Ab-R-MCF-7 were similar to the control cells. They exhibited a change of $1.04,0.80,1.14$, and 1.28 folds, respectively. However, in Ab-treated drug-sensitive cells, these gene expressions were found to be 2.25, 2.17, 2.14, and 5.17-folds higher, respectively (Fig. 2. C). BAX, BAD, Casp-3 and PARP1 expression in Pb-RMCF-7 was 1.15, 0.95, 1.0, and 1.20-fold changed, respectively, however, in Pb-treated, drug-sensitive cells, these were 2.25, 2.15, 2.51, and 3.86-fold higher, respectively, compared to the control (Fig. 2. D).

MDR-1 and ABCG-2 are two efflux proteins that are involved in drug expulsion and have been linked to cancer cell survival and resistance evolution. As depicted in Fig. 2A. MDR1 expression was found to be identical in control and drug-treated responsive cells. It was shown to be increased 3.0-fold and 8.2-folds in Ab-R-MCF-7 and Pb-R-MCF-7 cells, respectively. The expression of the ABCG2 gene was comparable in 
control and drug-treated responsive cells, but it was 4.0 and 5.9 times higher in Ab-RMCF-7 and Pb-RMCF-7 cells, respectively.

ESR1 genes are overexpressed in cancer cells, especially in breast cancer, and both $\mathrm{Ab}$ and $\mathrm{Pb}$ are CDK4/6 inhibitors. In this analysis, the expression of ESR-1, CDK-4, and CDK-6 in control and responsive cells was found to be identical, whereas the level of cyclin D1 decreased 0.55-fold.However, ESR-1, CDK-4, CDK-6, and Cyclin D1 genes increased 11.9, 3.6, 15.5, and 4.1-fold in Ab-resistant cells, respectively. In Pbresponsive cells ESR-1, CDK-4, and CDK-6 gene expression was unchanged compared to the controls, whereas, Cyclin-D1 was 0.43-fold down-regulated. However, in Pb-resistant cells, ESR-1, CDK-4, CDK-6, and Cyclin-D1 gene expression were increased 20.3, 2.8, 6.4, and 6.0-fold, respectively (Fig. 2. F). As a result, the upregulation of survival genes and the downregulation of apoptotic genes in qPCR results illustrate how these molecular modifications facilitate cell survival and drug tolerance.

\section{Differentially Expressed Proteins (Deps) In Global-profiling}

Global proteome profiling was used to assess altered protein expressions in Ab and Pb-resistant MCF-7 cells. In Ab-R-MCF-7 cells, 237 proteins were identified as DEPs, with 162 proteins were down-regulated and 75 being up-regulated. In Pb-R-MCF-7 cells, 239 proteins were identified as DEPs, with 153 proteins were down-regulated and 86 being up-regulated (Fig. 3A, B). Venn-diagram analysis in Fig. 3. C and D, has shown common proteins among different set of samples (Ab-RMCF- 7/MCF-7 control (Set1 F2/F1 and Set-2 F5/F4) and Pb-R-MCF-7/MCF-7control (Set-1 F3/F1 and Set-2 F6/F4)).DEPs in Ab-R-MCF-7 and PbR-MCF-7 cells were manually curated from the PubMed literature search engine, and their cancer-related functions were revealed. Down-regulation of NUDT5, PEPD, ABAT, ATP1B1, GGCT, SELENBP1, M6PR, STOM, and ACTN1 proteins in Ab-R-MCF-7 cells has been identified as a prognostic indicator or a new drug target for breast cancer. (Supplementary Table 2 and Table 1). The upregulation of SBSN, HSD17B10, CD9, PDIA3, PSMB4, SLC2A1, and VTN proteins in Ab-R-MCF-7 cells has been identified as a poor prognostic indicator or involved in acquired drug resistance, and has been proposed as a novel drug target for BC treatment (Supplementary Table 3 and Table 1). NUDT5, PEPD, and GGCT proteins, which have been identified as prognosis or drug-sensitive markers, were downregulated in Pb-R-MCF-7 cells (Supplementary Table 4 and Table 1). CD47, HIST1H2BN, LMNA, VTN, PSMB5, HBB, PSMA7, FLNB, PRDX4, VDAC1, GOT2, HSPA5, SERPINH1, EIF4A2, FTH1, and VIM proteins have been found to be upregulated in $\mathrm{Pb}-\mathrm{R}-\mathrm{MCF}-7$ cells, which are associated with poor prognosis or drug resistance markers (Supplementary Table 5 and Table 1). 
Table 1

Differentially expressed proteins (DEPs) in drug resistance MCF-7 vs MCF-7 control with p-value $\leq 0.05$ showed their molecular functions and role in BC.

\begin{tabular}{|c|c|c|c|c|}
\hline DEPs & $\begin{array}{l}\text { Fold } \\
\text { Chans }\end{array}$ & Molecular function & Earlier Reports & Ref. \\
\hline \multicolumn{5}{|c|}{ Ab-R-MCF-7 Vs MCF-7 } \\
\hline SBSN & 3.45 & & $\begin{array}{l}\text { Upregulated SBSN enhances Wnt/ } \\
\beta \text {-catenin signalling and promote } \\
\text { proliferation and tumorigenicity }\end{array}$ & $\begin{array}{l}36 \\
37\end{array}$ \\
\hline PDIA3 & 3.1 & $\begin{array}{l}\text { Catalyzes the } \\
\text { rearrangement of -S-S - } \\
\text { bonds in proteins }\end{array}$ & $\begin{array}{l}\text { High expression of PDIA3 drive } \\
\text { production of secretory proteins } \\
\text { and create favourable tumor } \\
\text { microenvironment for invasion and } \\
\text { metastasis }\end{array}$ & $\begin{array}{l}40 \\
41\end{array}$ \\
\hline CD9 & 2.2 & $\begin{array}{l}\text { Integral membrane protein } \\
\text { associated with integrins, } \\
\text { regulates platelet } \\
\text { activation and aggregation, } \\
\text { and cell adhesion }\end{array}$ & $\begin{array}{l}\text { Tumor microenvironment facilitate } \\
\text { CD9 mediated crosstalk between } \\
\text { bone marrow-derived mesenchymal } \\
\text { stem cells and breast cancer cells } \\
\text { (via CCL5, CCR5, and CXCR12) that } \\
\text { contributes to chemo resistance }\end{array}$ & 39 \\
\hline SLC2A1 & 2.2 & $\begin{array}{l}\text { Facilitative glucose } \\
\text { transporter responsible for } \\
\text { glucose uptake }\end{array}$ & $\begin{array}{l}\text { Aggressive growth of breast cancer } \\
\text { activate hypoxia inducing factor } \\
\text { HIF1 result in GLUT1 expression }\end{array}$ & $\begin{array}{l}42 \\
43\end{array}$ \\
\hline HSD17B10 & 1.88 & $\begin{array}{l}\text { Involved in fatty acid, } \\
\text { branched-chain amino acid } \\
\text { and steroid metabolism } \\
\text { pathways }\end{array}$ & $\begin{array}{l}\text { High level of HSD17B10 was } \\
\text { indicator for poor responders to the } \\
\text { chemotherapy in osteosarcoma }\end{array}$ & 38 \\
\hline VTN & 1.8 & $\begin{array}{l}\text { A cell adhesion and } \\
\text { spreading factor }\end{array}$ & $\begin{array}{l}\text { Downstream of VEGF/VEGFR and } \\
\text { PIJK/AKT signalling induces cell } \\
\text { migration and metastasis in breast } \\
\text { cancer }\end{array}$ & $\begin{array}{l}33 \\
34 \\
35\end{array}$ \\
\hline PSMB4 & 1.59 & $\begin{array}{l}\text { Proteolytic degradation of } \\
\text { mostly intra- cellular } \\
\text { proteins }\end{array}$ & $\begin{array}{l}\text { PSMB4 overexpression enhances } \\
\text { the cell growth and viability of } \\
\text { breast cancer cells leading to a } \\
\text { poor prognosis }\end{array}$ & 29 \\
\hline NUDT5 & 0.67 & $\begin{array}{l}\text { Act as ADP-sugar } \\
\text { pyrophosphatase in } \\
\text { absence of diphosphate or } \\
\text { catalyse the synthesis of } \\
\text { ATP in presence of } \\
\text { diphosphate }\end{array}$ & $\begin{array}{l}\text { Associated with low overall survival } \\
\text { in clear cell renal cell carcinoma } \\
\text { and poor prognosis }\end{array}$ & 23 \\
\hline GGCT & 0.63 & $\begin{array}{l}\text { Glutathione homeostasis, } \\
\text { release cyto-c from } \\
\text { mitochondria, induces } \\
\text { apoptosis. }\end{array}$ & $\begin{array}{l}\text { Component of GSH-pathway, its } \\
\text { lower expression led to } \\
\text { chemotherapy resistance in breast } \\
\text { cancer }\end{array}$ & 25 \\
\hline
\end{tabular}




\begin{tabular}{|c|c|c|c|c|}
\hline DEPs & $\begin{array}{l}\text { Fold } \\
\text { Chang }\end{array}$ & Molecular function & Earlier Reports & Ref. \\
\hline SELENBP1 & 0.51 & $\begin{array}{l}\text { Involved in intra-Golgi } \\
\text { protein transport }\end{array}$ & $\begin{array}{l}\text { ER + ve breast cancer patient with } \\
\text { low SELENBP1 have poorer } \\
\text { survival rate and induce resistance } \\
\text { to the anti-proliferative effects of } \\
\text { Selenium }\end{array}$ & 28 \\
\hline ATP1B1 & 0.48 & $\begin{array}{l}\text { ATP hydrolysis coupled } \\
\text { with } \mathrm{Na} / \mathrm{K} \text { ions exchange } \\
\text { across plasma membrane. }\end{array}$ & $\begin{array}{l}\text { Associated with metastasis is an } \\
\text { important cell energy conversion } \\
\text { system }\end{array}$ & 27 \\
\hline ABAT & 0.15 & $\begin{array}{l}\text { Catalyzes the conversion } \\
\text { of gamma-amino butyrate } \\
\text { and L-beta- } \\
\text { aminoisobutyrate to } \\
\text { succinate semialdehyde } \\
\text { and methyl-malonate } \\
\text { semialdehyde, respectively }\end{array}$ & $\begin{array}{l}\text { Inverse-correlation between ABAT } \\
\text { expression and therapy resistance } \\
\text { in inflammatory breast cancer }\end{array}$ & 26 \\
\hline PEPD & 0.14 & Collagen metabolism & $\begin{array}{l}\text { Exogenous PEPD bind and inhibit } \\
\text { Her-2 and EGFR signalling result in } \\
\text { growth inhibition in cancer cells. }\end{array}$ & 24 \\
\hline \multicolumn{5}{|c|}{ Pb-R-MCF-7 Vs MCF-7 Control } \\
\hline VIM & 38.0 & $\begin{array}{l}\text { Vimentins are class-III } \\
\text { intermediate filaments } \\
\text { found in various non- } \\
\text { epithelial cells, especially } \\
\text { mesenchymal cells }\end{array}$ & $\begin{array}{l}\text { Activation of Erk-signalling } \\
\text { promotes VIM over-expression } \\
\text { whereas, its elevated expression in } \\
\text { methotrexate and tamoxifen- } \\
\text { resistant breast cancer }\end{array}$ & 5859 \\
\hline SERPINH1 & 36.5 & $\begin{array}{l}\text { Chaperone protein involved } \\
\text { in collagen folding }\end{array}$ & $\begin{array}{l}\text { Showed positive correlation } \\
\text { between its expression and } \\
\text { aggressive phenotype of gastric } \\
\text { cancer }\end{array}$ & 3637 \\
\hline HSPA5 & 20.3 & $\begin{array}{l}\text { Endoplasmic reticulum } \\
\text { chaperone that plays a key } \\
\text { role in protein folding }\end{array}$ & $\begin{array}{l}\text { HSPA5 were upregulated in } \\
\text { Lapatinib resistance breast cancer } \\
\text { cells }\end{array}$ & $\begin{array}{l}53 \\
54\end{array}$ \\
\hline FTH1 & 14.5 & Iron homeostasis & $\begin{array}{l}\text { Up-regulated in doxorubicin } \\
\text { resistant breast cancer and } \\
\text { promotes EMT }\end{array}$ & 57 \\
\hline GOT2 & 11.1 & $\begin{array}{l}\text { Phenylalanine } \\
\text { metabolism and Glucose } \\
\text { metabolism }\end{array}$ & $\begin{array}{l}\text { ZBRK1 and BRCA1 complex bind to } \\
\text { the GOT2 promoter and regulate its } \\
\text { expression. Impaired complex } \\
\text { binding results in uncontrolled } \\
\text { expression result in aspartate and } \\
\text { a- ketoglutarate production leads to } \\
\text { cell proliferation }\end{array}$ & 52 \\
\hline
\end{tabular}




\begin{tabular}{|c|c|c|c|c|}
\hline DEPs & $\begin{array}{l}\text { Fold } \\
\text { Change }\end{array}$ & Molecular function & Earlier Reports & Ref. \\
\hline VDAC1 & 9.6 & $\begin{array}{l}\text { Present on outer } \\
\text { mitochondrial membrane } \\
\text { regulating metabolite and } \\
\text { ion exchange }\end{array}$ & $\begin{array}{l}\text { EIVDAC1upregulation promote cell } \\
\text { proliferation, indicator of poor } \\
\text { prognosis, involved in therapy } \\
\text { resistance towards BRD inhibitors } \\
\text { in breast cancer }\end{array}$ & 50 \\
\hline PRDX4 & 9.2 & $\begin{array}{l}\text { Catalyse hydrogen } \\
\text { peroxide and regulate } \\
\text { hydrogen peroxide } \\
\text { signalling }\end{array}$ & $\begin{array}{l}\text { Elevated expression may lead to } \\
\text { therapy resistance and tumor } \\
\text { recurrence }\end{array}$ & $\begin{array}{l}50 \\
51\end{array}$ \\
\hline HBB & 8.4 & $\begin{array}{l}\text { Oxygen transport from the } \\
\text { lung to the various } \\
\text { peripheral tissue }\end{array}$ & $\begin{array}{l}\text { Promote aggressiveness in breast } \\
\text { cancer cells and poor prognosis }\end{array}$ & 48 \\
\hline FLNB & 6.6 & $\begin{array}{l}\text { Connects cell membrane } \\
\text { constituents to the actin } \\
\text { cytoskeleton }\end{array}$ & $\begin{array}{l}\text { Induces EMT by releasing FOXC1 } \\
\text { transcription factor and expression } \\
\text { of EMT gene signatured in } \\
\text { tumorigenesis }\end{array}$ & 49 \\
\hline LMNA & 5.2 & $\begin{array}{l}\text { Nuclear lamina component, } \\
\text { maintaining nuclear } \\
\text { integrity }\end{array}$ & $\begin{array}{l}\text { Lower expression is indicator of } \\
\text { poor prognosis and shorter } \\
\text { outcome }\end{array}$ & 47 \\
\hline EIF4A2 & 5.5 & $\begin{array}{l}\text { ATP-dependent RNA } \\
\text { helicase which is a subunit } \\
\text { of the elF } 4 \text { F complex } \\
\text { involved in cap recognition } \\
\text { and is required for mRNA } \\
\text { binding to ribosome }\end{array}$ & $\begin{array}{l}\text { Targeting EIF4A2 by miR-5195-3p } \\
\text { reverse chemoresistance in TNBC } \\
\text { cells }\end{array}$ & 56 \\
\hline PSMA7 & 4.9 & $\begin{array}{l}\text { Proteolytic degradation of } \\
\text { intracellular proteins }\end{array}$ & $\begin{array}{l}\text { Elevated expression of PSMA7 in } \\
\text { gastric cancer is associated with } \\
\text { tumor invasion, metastasis, poor } \\
\text { survival and having prognostic as } \\
\text { well as diagnostic value }\end{array}$ & 32 \\
\hline PSMB5 & 4.1 & $\begin{array}{l}\text { Proteolytic degradation of } \\
\text { intracellular proteins }\end{array}$ & $\begin{array}{l}\text { High expression of PSMB5 } \\
\text { indicates worse survival and can be } \\
\text { severed as novel drug target }\end{array}$ & $\begin{array}{l}30 \\
31\end{array}$ \\
\hline VTN & 3.9 & $\begin{array}{l}\text { Extracellular matrix (ECM) } \\
\text { protein may be associated } \\
\text { with cell adhesion and } \\
\text { migration }\end{array}$ & $\begin{array}{l}\text { VTN is downstream of } \\
\text { VEGF/VEGFR and PIBK/AKT } \\
\text { signalling induces cell migration } \\
\text { and metastasis in breast cancer }\end{array}$ & $\begin{array}{l}34 \\
35\end{array}$ \\
\hline HIST1H2BN & 2.7 & $\begin{array}{l}\text { Core component of } \\
\text { nucleosome }\end{array}$ & $\begin{array}{l}\text { Uncontrolled HIST1H2BN } \\
\text { expression contributes to cancer } \\
\text { initiation, progression, and } \\
\text { indicator of poor prognosis in } \\
\text { ovarian cancer }\end{array}$ & 46 \\
\hline
\end{tabular}




\begin{tabular}{|c|c|c|c|c|}
\hline DEPs & $\begin{array}{l}\text { Fold } \\
\text { Change }\end{array}$ & Molecular function & Earlier Reports & Ref. \\
\hline CD47 & 2.2 & $\begin{array}{l}\text { Membrane transport and } \\
\text { signal transduction }\end{array}$ & $\begin{array}{l}\text { HIF- } 1 \text { activates CD } 47 \text { transcription } \\
\text { in hypoxic condition, CD } 47 \\
\text { maintains cancer stem cells, induce } \\
\text { EMT and serve as indicator of poor } \\
\text { prognosis in breast cancer }\end{array}$ & $\begin{array}{l}44 \\
45\end{array}$ \\
\hline GGCT & 0.61 & $\begin{array}{l}\text { Glutathione homeostasis, } \\
\text { induces release of } \\
\text { cytochrome c from } \\
\text { mitochondria to induce } \\
\text { apoptosis }\end{array}$ & $\begin{array}{l}\text { Component of GSH-pathway, its } \\
\text { lower expression led to } \\
\text { chemotherapy resistance in breast } \\
\text { cancer }\end{array}$ & 25 \\
\hline PEPD & 0.28 & Collagen metabolism & $\begin{array}{l}\text { Exogenous PEPD bind and inhibit } \\
\text { Her-2 and EGFR signalling result in } \\
\text { growth inhibition in cancer cells }\end{array}$ & 24 \\
\hline NUDT5 & 0.22 & $\begin{array}{l}\text { Act as ADP-sugar } \\
\text { pyrophosphatase in } \\
\text { absence of diphosphate or } \\
\text { catalyse the synthesis of } \\
\text { ATP in presence of } \\
\text { diphosphate }\end{array}$ & $\begin{array}{l}\text { Associated with low overall survival } \\
\text { in clear cell renal cell carcinoma } \\
\text { and poor prognosis }\end{array}$ & 23 \\
\hline
\end{tabular}

GO-terms of DEPs in drug-resistant-MCF-7 cells were conducted. Ab-resistant cells' down-regulated proteins have been related to 87 bioprocesses, 23 molecular functions, and 63 cellular components and further KEGG pathway analysis identified 11 signaling pathways. Similarly, Ab-resistant cells' upregulated proteins have been related to 29 bioprocesses, 30 molecular functions, 30 cellular components and further KEGG pathway analysis identified 9 signaling pathways (Fig. 4. B). GO-term analysis in Pbresistant cells' down-regulated proteins have been related to 143 bioprocesses, 31 molecular functions, 63 cell components, and further KEGG pathway analysis identified 32 signaling pathways. Similarly, Abresistant cells' up-regulated proteins have been related to 30 bioprocess, 28 molecular functions, 30 cellular components and further KEGG pathway analysis identified 30 signaling pathways. (Fig. 5. A, B).We analysed both drug resistance samples using the Reactome pathway database to investigate the reactome pathway associated with these two conditions. DEPs are implicated in metabolism, immunity, signal transduction, programmed cell death, cellular response to external stimuli, DNA replication, cell cycle, and vesicle transport in this study. (Fig. 6A, B, C, and D).

Hub molecules in DEP's dataset were identified by the Network Analysis tool. FLNA, SSBP, SLC3A2, ATP5B, DLD, and SOD1 were found to be major hubs among down-regulated proteins, whereas, S100A7, VTN, and RAD are up-regulated proteins were identified as major hubs in Ab-resistance cells. YWHAZ, DDB1, HSPB1, S100A9, and ANXA2 were found to be major hubs among down-regulated proteins, while SERPINH1, AHCY, FBP1, TXNRD1, PSMA6, HSP90B1, and PKM were found to be major hubs among upregulated proteins in Pb-resistance cells. (Fig. 7. A, B, C, and D). 
The miR-Net tool was used to analyse miRNA-protein interactions and find an inverse association between miRNAs and their targeted DEPs. In Ab-resistance cells, hsa-mir-1-3p, hsa-mir-155-5p, and hsamir-24-p with down-regulated proteins and hsa-mir-155-5p, hsa-mir-23b-3p, hsa-mir-124-3p, and has-mir$30 a-5 p$ with up-regulated DEPs showed an inverse relationship. hsa-mir-155-5p, has-mir-1-3p, hsa-mir20a-5p, and hsa-mir-182-5p with down-regulated proteins and hsa-mir-130a-3p, hsa-mir-101-3p, hsa-mir19a-3p, hsa-mir-34a-5p, and hsa-let-7a-5p with up-regulated proteins showed an inverse correlation in $\mathrm{Pb}$ resistance cells.

\section{Discussion}

Drug-resistant MCF-7 cells showed to tolerate the drug at higher concentrations compared to control cells. Microscopic images of PI-stained cells confirmed the findings.MDR-1 and ABCG-2 are xenobiotic transporters that help cells eliminate toxins. These proteins have been linked to the phenotype of drug resistance in various cancers $[18,19]$.Increased MDR-1 and ABCG-2 expression in MCF-7 cells exposed with $\mathrm{Ab}$ and $\mathrm{Pb}$ for a long-time result in drug efflux, which may be one of the reasons for drug resistance in these cells.

As shown in Fig. 2B, $C$, and $D$, the drug-resistance models were re-confirmed by increased expression of survival (BCl-2 and MCL-1) genes and suppressed expression of pro-apoptotic (BAX, BAD, Caspase-3, and PARP1) genes. Bcl-2 blocks the intrinsic apoptosis signal by inhibiting Bax and Bak interactions on the mitochondrial outer membrane. Drug-resistant, cells have elevated levels of Bcl-2 and MCL-1 [20, 21]. Estrogen activates ER, which leads to DNA replication and cell division, as encoded by the ESR1 gene [22].Increased ESR 1 expression suggests that it can contribute to therapy resistance. CDK4 and CDK6 are targeted by $\mathrm{Ab}$ and $\mathrm{Pb}$, which stimulates cyclin-D1 and promotes cell cycle progression. Increased CDK4/ 6 and cyclin D1 expression in our cells promotes successful cell division, which is a hallmark of drug resistance.

The roles of proteins in therapy resistance in Ab-R-MCF-7 and Pb-R-MCF-7 cells are described in Supplementary table 2-5. DEPs are manually curated from the PubMed literature search engine to determine their molecular functions, roles in cancer progression, therapy resistance, and prognostic importance (see Table 1). NUDT5 is linked to a poor prognosis and low overall survival in clear cell renal cell carcinoma [23]. PEPD binds to Her-2 and inhibits EGFR signaling, resulting in cancer cell growth inhibition [24]. Lower expression of GGCT, a crucial component of the GSH-pathway, has been linked to chemo-resistance [25]. Inflammatory BC has an inverse association between ABAT expression and therapy resistance [26]. A high level of ATP1B1 is linked to metastasis and it is an essential energy transfer system for cells [27]. Low levels of SELENBP1 in ER + ve BC result in poor survival and selenium tolerance [28] (Supplementary table 2 and 4 ) and Table 1.

PSMB is a group $\beta$-subunit of the 20S proteasome (PSMB4 and PSMB5), and a-subunit PSMA7 are involved in the proteolytic degradation of intracellular proteins. PSMB4 overexpression promotes cell cycle progression from $\mathrm{G} 1$ to $S$ phase and cell viability through NF-B signaling [29]. A high PSMB5 level 
suggests a poor prognosis [30, 31]. PSMA7 levels in gastric cancer have been related to invasion, metastasis, and poor prognosis [32]. VTN is a part of the extracellular matrix that promotes integrin signaling. VTN, which is downstream of VEGF/VEGFR and PI3K/AKT signaling, promotes cell migration and metastasis in breast cancer $[33,34,35]$. SBSN is an oncoprotein that promotes tumorigenicity by increasing Wnt/ $\beta$-catenin signaling $[36,37]$. The mitochondrial enzyme HSB17B10 is responsible for the oxidation of steroids, alcohol, and fatty acids. In osteosarcoma, a high level of HSD17B10 indicated a poor response to chemotherapy [38]. Chemo-resistance is caused by the tumour microenvironment facilitating CD9-mediated crosstalk between mesenchymal stem cells and BC cells via CCL5, CCR5, and CXCR12 [39]. PDIA3 expression in the tumor microenvironment is high, which favors invasion and metastasis [40, 41].GLUT1 proteins encoded by SLC2A1 aid glucose transport. Hypoxia inducing factor1 (HIF-1) is activated as breast cancer grows aggressively. Due to hypoxic environments, HIF1 triggers GLUT1 expression [42, 43]. Under hypoxic conditions, HIF-1 also activates CD47 transcription. In BC, CD47 retains stemness, induces EMT and leads to a poor prognosis $[44,45]$. HIST1H2BN is a part of the H2B protein family whose unregulated expression causes cancer and is a predictor of poor prognosis in ovarian cancer [46]. Hemoglobin beta (HBB) is an oxygen transporter that promotes BC cell aggression and a poor prognosis [48]. By releasing FOXC1 transcription factor, FLNB exon 30 skipping (gene splicing) induces EMT, and expression of EMT gene signature induces tumorigenicity [49]. Cancer stem cell survival and proliferation are influenced by redox control and oxidative stress. Peroxiredoxin 4 (PRDX4) catalyses hydrogen peroxide and regulate hydrogen peroxide signaling leading to tumor recurrence and therapy resistance [50,51]. BRD4 is a downstream target of voltage-dependent anion channels (VDAC1), which are found on the outer mitochondrial membrane. VDAC1 overexpression causes breast cancer proliferation, is associated with a poor prognosis, and is linked to therapy resistance to BRD inhibitors in BC [50]. The GOT2 promoter is regulated by the ZBRK1 and BRCA1 complex, which binds to it and regulates its expression. Impaired complex binding contributes to uncontrollable expression, which promotes cell proliferation [52]. In lapatinib-resistant BC, a high level of HSPA5 was found [53, 54]. SERPINH 1 is a chaperone protein, and its high expression has been linked to a more aggressive phenotype of gastric cancer, implying a poor prognosis [36, 37]. miR-5195-3p targets EIF4A2, which can reverse chemoresistance in TNBC cells [56]. FTH1 is a subunit of the ferritin complex that promotes EMT in doxorubicin-resistant breast cancer [57]. Vimentin (VIM) is a member of the intermediate filament protein family that contributes to cell invasion, migration, and signaling. VIM expression is promoted by Erk signaling activation. Its increased expression has been identified in methotrexate and tamoxifenresistant BC. [58, 59].

GO-terms of down-regulated DEPs in Ab and Pb-resistant cells were as follows: biological processes were identified asapoptosis, cell adhesion, small molecule catabolic processes, cofactor metabolic processes, nucleotide metabolic processes, and carbohydrate metabolic processes, etc. The cell surface, mitochondria, endoplasmic reticulum, extracellular matrix, and chaperone complex, among other cellular components were established. Signaling pathways such as estrogen, metabolic pathway and pyruvate metabolism, gluconeogenesis, TCA-cycle, and MAPK-pathway were established (Fig. 4. A). Up-regulated DEPs in $\mathrm{Ab}$ and $\mathrm{Pb}$ resistance cells are linked to biological processes such as cell activation, generation 
of precursor metabolites, and energy, lung development, cellular response to chemical stimuli, response to hypoxia, cellular response to cytokine stimulus and small molecule metabolic processes. Cellular components localized in the mitochondrial membrane, cytoplasmic vesicle, extracellular matrix, secretoryvesicle and outer membrane. Signaling pathways such as metabolic pathways, insulin signaling, Choline metabolism in cancer, CGMP-PKG-signalling, Gluconeogenesis, ECM receptor interaction and MAPK signaling, NOTCH signaling, Wnt/ $\beta$-catenin, PI3K/AKT/mTOR, JAK-STAT, TGF- $\beta$ signaling these terms are more active in tumor progression, cancer recurrence and therapy resistance.

During the treatment of a breast cancer patient, tumor cells can develop therapy resistance to Abemaciclib and Palbociclib drugs. In Ab-resistant cells, a set of down-regulated proteins (NUDT5, PEPD, ABAT, ATP1B1, GGCT, SELENBP1, M6PR, STOM, and ACTN1) as well as up-regulated proteins (SBSN, HSD17B10, CD9, PDIA3, PSMB4, SLC2A1, and VTN) may be useful for prognosis and may be a new drug target.Similarly, in Pb-resistant cells, a series of down-regulated proteins (NUDT5, PEPD, and GGCT) as well as up-regulated proteins (CD47, HIST1H2BN, LMNA, VTN, PSMB5, HBB, PSMA7, FLNB, PRDX4, VDAC1, GOT2, HSPA5, SERPINH1, EIF4A2, FTH, and VIM) may be useful for prognosis and may be a new drug target. However, further confirmation of these DEPs for their prognostic and therapeutic roles in BC would involve either an in vivo analysis or a study on clinical samples. Many miRNAs need to be confirmed for their functional role in therapy resistance, according to a miRNA-protein network review of DEPs.

\section{Abbreviations}

DEPs: Differentially expressed proteins

CDK: cyclin-dependent kinase,

PI: Propidium lodide,

Ab-R-MCF-7 Abemacilcib resistance MCF-7

Pb-R-MCF-7: Palbociclib resistance MCF-7,

Ab: Abemaciclib,

Pb: Palbocilcib and

BC: Breast cancer.

\section{Declarations}

Authors' contributions 
Conceptualization: Binayak Kumar, Data curation: Ram Krishna Sahu and Ragini Singh, Funding acquisition: Binayak Kumar, Project administrator and Supervision: Suresh T. Hedau, Visualization: Ashutosh Singh, Peeyush Prasad, Writing original draft: Binayak Kumar. Writing, review and editing Binayak Kumar, Srikrishna Jayadev M and Suresh T. Hedau.

\section{Acknowledgments}

I want to thank the Indian Council of Medical Research for providing Post-Doctoral fellowship, National Institute of Cancer Prevention and Research for providing lab facility to conduct proposed work. I want to thank School of Life Sciences, Shiv Nadar University to conduct part of work there. I want to thank MASSFIITB facility at IIT Bombay, Mumbai for conducting non-labelled global proteome profiling.

\section{Funding}

The Project was supported by the Indian Council of Medical Research, India in 2018, No. 3/1/3/PDF (17)/2017-HRD.

Conflict of interest: Authors declare that they have no conflict of interest.

\section{Supplementary data}

Supplementary Table 1: List of genes and their primer sequences.

Supplementary Table 2: List of down-regulated proteins in Ab-R-MCF-7 and their references.

Supplementary Table 3: List of Up-regulated genes in Ab-R-MCF-7 cells and their references.

Supplementary Table 4: List of down-regulated Proteins in Pb-R-MCF-7 cells and their references.

Supplementary Table 5: List of Proteins up-regulated in Pb-R-MCF-7 cells and their references.

\section{Ethics approval and consent to participate.}

Not Applicable.

\section{Consent for publication}

Not applicable

\section{Availability of data and materials}

All data generated or analysed during this study are included in this published article [and its Supplementary information files]. 


\section{References}

1. Bray F, Ferlay J, Soerjomataram I, Siegel RL, Torre LA, Jemal A (2020 Jul;70(4):313]) Global cancer statistics 2018: GLOBOCAN estimates of incidence and mortality worldwide for 36 cancers in 185 countries [published correction appears in CA Cancer J Clin. CA Cancer J Clin. 2018;68(6):394-424. doi:10.3322/caac.21492

2. Curado MP, Edwards B, Shin HR, Storm H, Ferlay J, Heanue M, Boyle P (eds) (2007) Cancer Incidence in Five Continents, vol IX. IARC Scientific Publications No. 160, Lyon

3. Forman D, Bray F, Brewster DH, Gombe Mbalawa C, Kohler B, Piñeros M, Steliarova- Foucher E, Swaminathan R, Ferlay J eds (2013) Cancer Incidence in Five Continents, Vol. X (electronic version) Lyon, IARC

4. Saini KS, Taylor C, Ramirez AJ, Palmieri C, Gunnarsson U, Schmoll HJ, Dolci SM, Ghenne C, MetzgerFilho O, Skrzypski M, Paesmans M, Ameye L, Piccart-Gebhart MJ, de Azambuja E (2012 Apr) Role of the multidisciplinary team in breast cancer management: results from a large international survey involving 39 countries. Ann Oncol 23(4):853-859. doi:10.1093/annonc/mdr352

5. Li Y, Wang Y, Wang H, Zhang L, Ding Y, Chen S, Yang Q, Chen C. Effects of IncRNA RP11-770J1.3 and TMEM25 expression on paclitaxel resistance in human breast cancer cells. 2017 Jul 25;46(4):364370

6. Zhou H, Lv Q, Guo Z (2018 Feb) Transcriptomic signature predicts the distant relapse in patients with ER + breast cancer treated with tamoxifen for five years. Mol Med Rep 17(2):3152-3157. doi:10.3892/mmr.2017.8234

7. Asghar U, Witkiewicz AK, Turner NC, Knudsen ES (2015 Feb) The history and future of targeting cyclin-dependent kinases in cancer therapy. Nat Rev Drug Discov 14(2):130-146. doi:10.1038/nrd4504

8. Beaver JA, Amiri-Kordestani L, Charlab R, Chen W, Palmby T, Tilley A, Zirkelbach JF, Yu J, Liu Q, Zhao L, Crich J, Chen XH, Hughes M, Bloomquist E, Tang S, Sridhara R, Kluetz PG, Kim G, Ibrahim A, Pazdur R, Cortazar P. FDA Approval: Palbociclib for the Treatment of Postmenopausal Patients with Estrogen Receptor-Positive, HER2-Negative Metastatic Breast Cancer. Clin Cancer Res. 2015 Nov 1;21(21):4760-6. doi: 10.1158/1078-0432

9. Patnaik A, Rosen LS, Tolaney SM, Tolcher AW, Goldman JW, Gandhi L, Papadopoulos KP, Beeram M, Rasco DW, Hilton JF, Nasir A, Beckmann RP, Schade AE, Fulford AD, Nguyen TS, Martinez R, Kulanthaivel P, Li LQ, Frenzel M, Cronier DM, Chan EM, Flaherty KT, When PY, Shapiro GI (2016 Jul) Efficacy and Safety of Abemaciclib, an Inhibitor of CDK4 and CDK6, for Patients with Breast Cancer, Non-Small Cell Lung Cancer, and Other Solid Tumors. Cancer Discov 6(7):740-753. doi:10.1158/2159-8290.CD-16-0095

10. Burkhart DL, Sage J (2008) Cellular mechanisms of tumor suppression by the retinoblastoma gene. Nat Rev Cancer 8(9):671-682. doi:10.1038/nrc2399 
11. Musgrove EA, Caldon CE, Barraclough J, Stone A, Sutherland RL (2011) Cyclin D as a therapeutic target in cancer. Nat Rev Cancer 11(8):558-572. doi:10.1038/nrc3090. Published 2011 Jul 7.

12. Koboldt DC, Zhang Q, Larson DE et al (2012) VarScan 2: somatic mutation and copy number alteration discovery in cancer by exome sequencing. Genome Res 22(3):568-576. doi:10.1101/gr.129684.111

13. Shapiro GI (2006) Cyclin-dependent kinase pathways as targets for cancer treatment. J Clin Oncol 24(11):1770-1783. doi:10.1200/JC0.2005.03.7689

14. Guarducci C, Bonechi M, Boccalini G et al (2017) Mechanisms of Resistance to CDK4/6 Inhibitors in Breast Cancer and Potential Biomarkers of Response. Breast Care (Basel) 12(5):304-308. doi:10.1159/000484167

15. Pandey K, An HJ, Kim SK et al (2019) Molecular mechanisms of resistance to CDK4/6 inhibitors in breast cancer: A review. Int J Cancer 145(5):1179-1188. doi:10.1002/ijc.32020

16. Portman N, Alexandrou S, Carson E, Wang S, Lim E, Caldon CE (2019) Overcoming CDK4/6 inhibitor resistance in ER-positive breast cancer. EndocrRelat Cancer 26(1):R15-R30. doi:10.1530/ERC-180317

17. Jansen VM, Bhola NE, Bauer JA et al. Kinome-Wide RNA Interference Screen Reveals a Role for PDK1 in Acquired Resistance to CDK4/6 Inhibition in ER-Positive Breast Cancer [published correction appears in Cancer Res. 2019 Feb 15;79(4):874]. Cancer Res. 2017;77(9):2488-2499. doi: 10.1158/0008-5472.CAN-16-2653

18. Kovalev AA, Tsvetaeva DA, Grudinskaja TV (2013) Role of ABC-cassette transporters (MDR1, MRP1, BCRP) in the development of primary and acquired multiple drug resistance in patients with early and metastatic breast cancer. Exp Oncol 35(4):287-290

19. Qu H, Fang L, Duan L, Long X (2014) Zhonghua Bing Li Xue Za Zhi 43(4):236-240

20. Zhang M, Guo R, Zhai Y, Yang D (2003) LIGHT sensitizes IFNgamma-mediated apoptosis of MDAMB-231 breast cancer cells leading to down-regulation of anti-apoptosis Bcl-2 family members. Cancer Lett 195(2):201-210. doi:10.1016/s0304-3835(03)00148-4

21. Lin F, Luo J, Gao W et al (2013) COX-2 promotes breast cancer cell radioresistance via p38/MAPKmediated cellular anti-apoptosis and invasiveness. Tumour Biol 34(5):2817-2826. doi:10.1007/s13277-013-0840-x

22. La Rosa P, Pesiri V, Marino M, Acconcia F (2011) 17ß-Estradiol-induced cell proliferation requires estrogen receptor (ER) a monoubiquitination. Cell Signal 23(7):1128-1135. doi:10.1016/j.cellsig.2011.02.006

23. Wang Y, Wan F, Chang K, Lu X, Dai B, Ye D (2017) NUDT expression is predictive of prognosis in patients with clear cell renal cell carcinoma. Oncol Lett 14(5):6121-6128. doi:10.3892/ol.2017.6997

24. Yang L, Li Y, Bhattacharya A, Zhang Y. A recombinant human protein targeting HER2 overcomes drug resistance in HER2-positive breast cancer. Sci Transl Med. 2019;11(476): eaav1620. doi:10.1126/scitranslmed. aav1620 
25. Wang Z, Liang S, Lian X et al. Identification of proteins responsible for Adriamycin resistance in breast cancer cells using proteomics analysis. Sci Rep. 2015; 5:9301. Published 2015 Mar 30. doi:10.1038/srep0930

26. Jansen MP, Sas L, Sieuwerts AM et al (2015) Decreased expression of ABAT and STC2 hallmarks ERpositive inflammatory breast cancer and endocrine therapy resistance in advanced disease. Mol Oncol 9(6):1218-1233. doi:10.1016/j.molonc.2015.02.006

27. Qi YY, Liu K, Zhang J, Li K, Ren JJ, Lin P (2009) Ai Zheng 28(8):861-867. doi:10.5732/cjc.009.10004

28. Wang $Y$, Fang $W$, Huang $Y$ et al (2015) Reduction of selenium-binding protein 1 sensitizes cancer cells to selenite via elevating extracellular glutathione: a novel mechanism of cancer-specific cytotoxicity of selenite. Free RadicBiol Med 79:186-196. doi:10.1016/j.freeradbiomed.2014.11.015

29. Wang H, He Z, Xia L et al (2018) PSMB4 overexpression enhances the cell growth and viability of breast cancer cells leading to a poor prognosis. Oncol Rep 40(4):2343-2352. doi:10.3892/or.2018.6588

30. Wei W, Zou Y, Jiang Q et al (2018) PSMB5 is associated with proliferation and drug resistance in triple-negative breast cancer. Int J Biol Markers 33(1):102-108. doi:10.5301/ijbm.5000283

31. Wang CY, Li CY, Hsu HP, Cho CY, Yen MC, Weng TY, Chen WC, Hung YH, Lee KT, Hung JH, Chen YL, Lai MD. PSMB5 plays a dual role in cancer development and immunosuppression. Am J Cancer Res. 2017 Nov 1;7(11):2103-2120

32. Xia S, Tang Q, Wang X, Zhang L, Jia L, Wu D, Xu P, Zhang X, Tang G, Yang T, Feng Z, Lu L (2019 Nov) Overexpression of PSMA7 predicts poor prognosis in patients with gastric cancer. Oncol Lett 18(5):5341-5349. doi:10.3892/ol.2019.10879. Epub 2019 Sep 19

33. Liu D, Zhou D, Wang B, Knabe WE, Meroueh SO (2015) A new class of orthostericuPAR.uPA smallmolecule antagonists are allosteric inhibitors of the UPAR vitronectin interaction. ACS Chem Biol. Jun 19;10(6):1521-34. doi: 10.1021/cb500832q. Epub 2015 Mar 31

34. Bera A, Subramanian M, Karaian J, Eklund M, Radhakrishnan S, Gana N, Rothwell S, Pollard H, Hu H, Shriver CD, Srivastava M. Functional role of vitronectin in breast cancer. PLoS One. $2020 \mathrm{Nov}$ 19;15(11): e0242141. doi: 10.1371/journal.pone.0242141

35. Lian L, Li XL, Xu MD et al (2019) VEGFR2 promotes tumorigenesis and metastasis in a proangiogenic- independent way in gastric cancer. BMC Cancer 19(1):183. doi:10.1186/s12885-0195322-0. Published 2019 Feb 28.

36. Zhu J, Xiong G, Fu H, Evers BM, Zhou BP, Xu R (2015) Chaperone Hsp47 Drives Malignant Growth and Invasion by Modulating an ECM Gene Network. Cancer Res 75(8):1580-1591. doi:10.1158/0008-5472.CAN-14-1027

37. Hubackova S, Pribyl M, Kyjacova L et al (2019) Interferon-regulated suprabasin is essential for stress-induced stem-like cell conversion and therapy resistance of human malignancies. Mol Oncol 13(7):1467-1489. doi:10.1002/1878-0261.12480

38. Salas S, Jézéquel P, Campion L et al (2009) Molecular characterization of the response to chemotherapy in conventional osteosarcomas: predictive value of HSD17B10 and IFITM2. Int J 
Cancer 125(4):851-860. doi:10.1002/ijc.24457

39. Ullah M, Akbar A, Ng NN, Concepcion W, Thakor AS (2019) Mesenchymal stem cells confer chemoresistance in breast cancer via a CD9-dependent mechanism. Oncotarget 10(37):3435-3450. doi:10.18632/oncotarget.26952. Published 2019 May 28.

40. Ramos FS, Serino LT, Carvalho CM, Lima RS, Urban CA, Cavalli IJ, Ribeiro EM. PDIA3 and PDIA6 gene expression as an aggressiveness marker in primary ductal breast cancer. Genet Mol Res. 2015 Jun 26;14(2):6960-7. doi: 10.4238/2015.June.26.4

41. Young HS, McGowan LM, Jepson KA, Adams JC. Impairment of cell adhesion and migration by inhibition of protein disulfide isomerases in three breast cancer cell lines. Biosci Rep. 2020 Oct 30;40(10): BSR20193271. doi: 10.1042/BSR20193271

42. He Y, Deng F, Zhao $S$ et al (2019) Analysis of miRNA-mRNA network reveals miR-140-5p as a suppressor of breast cancer glycolysis via targeting GLUT1. Epigenomics 11(9):1021-1036. doi:10.2217/epi-2019-0072

43. Hamann I, Krys D, Glubrecht D, Bouvet V, Marshall A, Vos L, Mackey JR, Wuest M, Wuest F. Expression and function of hexose transporters GLUT1, GLUT2, and GLUT5 in breast cancer-effects of hypoxia. FASEB J. 2018 Sep;32(9):5104-5118. doi: 10.1096/fj.201800360R. Epub 2018 Apr 13. PMID: 29913554

44. Zhang H, Lu H, Xiang L, Bullen JW, Zhang C, Samanta D, Gilkes DM, He J, Semenza GL. HIF-1 regulates CD47 expression in breast cancer cells to promote evasion of phagocytosis and maintenance of cancer stem cells. Proc Natl Acad Sci U S A. 2015 Nov 10;112(45):E6215-23. doi: 10.1073/pnas.1520032112. Epub 2015 Oct 28

45. Yuan J, Shi X, Chen C et al (2019) High expression of CD47 in triple negative breast cancer is associated with epithelial-mesenchymal transition and poor prognosis. Oncol Lett 18(3):3249-3255. doi:10.3892/ol.2019.10618

46. Liao YP, Chen LY, Huang RL et al (2014) Hypomethylation signature of tumor-initiating cells predicts poor prognosis of ovarian cancer patients. Hum Mol Genet 23(7):1894-1906. doi:10.1093/hmg/ddt583

47. Alhudiri IM, Nolan CC, Ellis IO et al (2019) Expression of Lamin A/C in early-stage breast cancer and its prognostic value. Breast Cancer Res Treat 174(3):661-668. doi:10.1007/s10549-018-05092-w

48. Ponzetti M, Capulli M, Angelucci A et al (2017) Non-conventional role of haemoglobin beta in breast malignancy. Br J Cancer 117(7):994-1006. doi:10.1038/bjc.2017.247

49. Li J, Choi PS, Chaffer CL, Labella K, Hwang JH, Giacomelli AO, Kim JW, llic N, Doench JG, Ly SH, Dai C, Hagel K, Hong AL, Gjoerup O, Goel S, Ge JY, Root DE, Zhao JJ, Brooks AN, Weinberg RA, Hahn WC. An alternative splicing switch in FLNB promotes the mesenchymal cell state in human breast cancer. Elife. 2018 Jul 30;7: e37184. doi: 10.7554/eLife.37184

50. Yang G, Zhou D, Li J et al (2019) VDAC1 is regulated by BRD4 and contributes to JQ1 resistance in breast cancer. Oncol Lett 18(3):2340-2347. doi:10.3892/ol.2019.10534 
51. Jia W, Chen P, Cheng Y (2019 Jan) PRDX4, and Its Roles in Various Cancers. Technol Cancer Res Treat 1:18:1533033819864313. doi:10.1177/1533033819864313

52. Hong R, Zhang W, Xia X, Zhang K, Wang Y, Wu M, Fan J, Li J, Xia W, Xu F, Chen J, Wang S, Zhan Q. Preventing BRCA1/ZBRK1 repressor complex binding to the GOT2 promoter results in accelerated aspartate biosynthesis and promotion of cell proliferation. Mol Oncol. 2019 Apr;13(4):959-977. doi: 10.1002/1878-0261.12466. Epub 2019 Mar 1

53. Zhang L, Huang Y, Zhuo W, Zhu Y, Zhu B, Chen Z (2017 May) Identification, and characterization of biomarkers and their functions for Lapatinib-resistant breast cancer. Med Oncol 34(5):89. doi:10.1007/s12032-017-0953-y. Epub 2017 Apr 9

54. Chang YW, Tseng CF, Wang MY et al (2020 Jan;39(4):946-949]) Deacetylation of HSPA5 by HDAC6 leads to GP78- mediated HSPA5 ubiquitination at K447 and suppresses metastasis of breast cancer [published correction appears in Oncogene. Oncogene. 2016;35(12):1517-1528

55. Kawagoe K, Wada M, Idichi T, Okada R, Yamada Y, Moriya S, Okubo K, Matsushita D, Arigami T, Kurahara H, Maemura K, Natsugoe S, Seki N. Regulation of aberrantly expressed SERPINH1 by antitumor miR-148a-5p inhibits cancer cell aggressiveness in gastric cancer. J Hum Genet. 2020 Aug;65(8):647-656. doi: 10.1038/s10038-020-0746-6. Epub 2020 Mar 31

56. Liu M, Gong C, Xu R, Chen Y, Wang X. MicroRNA-5195-3p enhances the chemosensitivity of triplenegative breast cancer to paclitaxel by downregulating mEIF4A2. Cell Mol Biol Lett. 2019;24:47. Published 2019 Jul 1. doi:10.1186/s11658-019-0168-7

57. Bigagli E, Cinci L, D'Ambrosio M, Luceri C (2019) Transcriptomic Characterization, Chemosensitivity and Regulatory Effects of Exosomes in Spontaneous EMT/MET Transitions of Breast Cancer Cells. Cancer Genomics Proteomics 16(3):163-173. doi:10.21873/cgp.20122

58. Chen S, Cai J, Zhang W, Zheng X, Hu S, Lu J, Xing J, Dong Y (2014 Jul) Proteomic identification of differentially expressed proteins associated with the multiple drug resistance in methotrexateresistant human breast cancer cells. Int J Oncol 45(1):448-458. doi:10.3892/ijo.2014.2389. Epub 2014 Apr 16

59. Lakhtakia R, Aljarrah A, Furrukh M, Ganguly SS (2017) Epithelial Mesenchymal Transition (EMT) in Metastatic Breast Cancer in Omani Women. Cancer Microenviron 10(1-3):25-37.

doi:10.1007/s12307-017-0194-9

\section{Figures}


A Cell-Viability Assay Ab treated for $\mathbf{4 8 ~ h r s ~}$

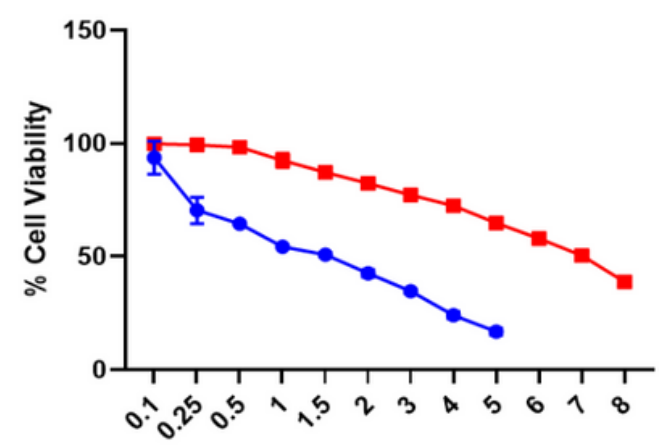

Concentration $(\mu \mathrm{M})$

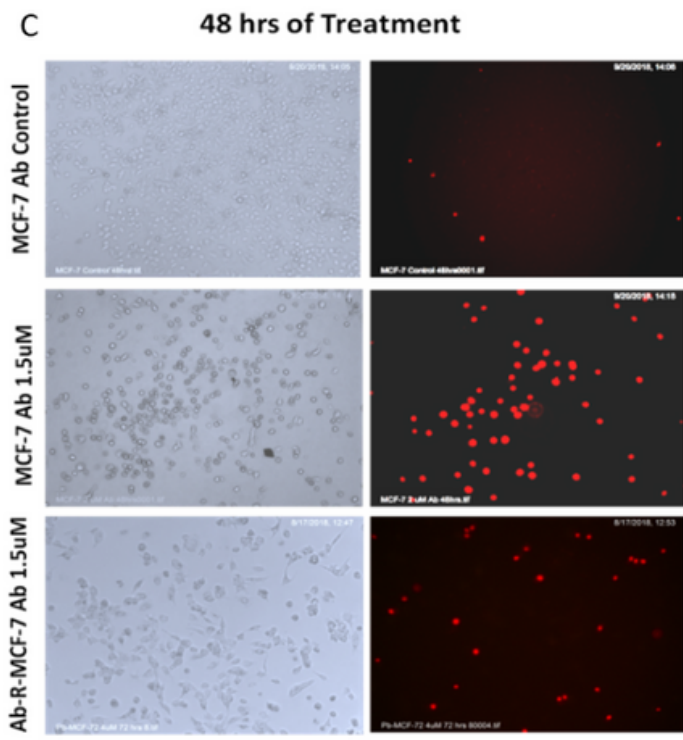

- MCF-7

- Ab-R-MCF-7

Concentration $(\mu \mathrm{M})$

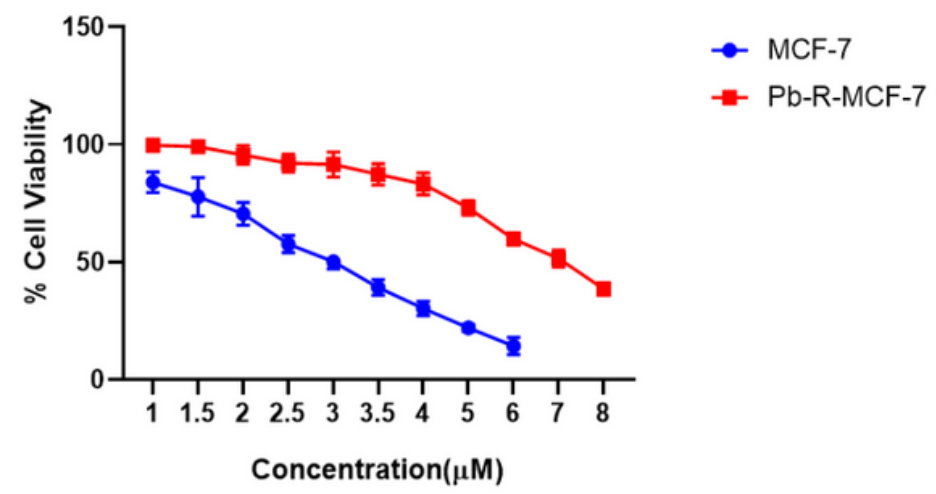

B Cell-Viability Assay $\mathrm{Pb}$ treated for $72 \mathrm{hrs}$
D
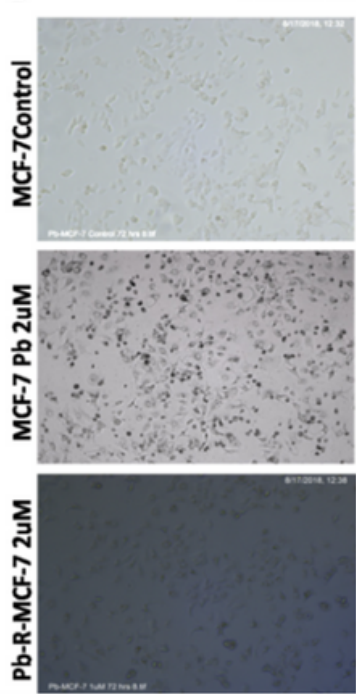

$E$
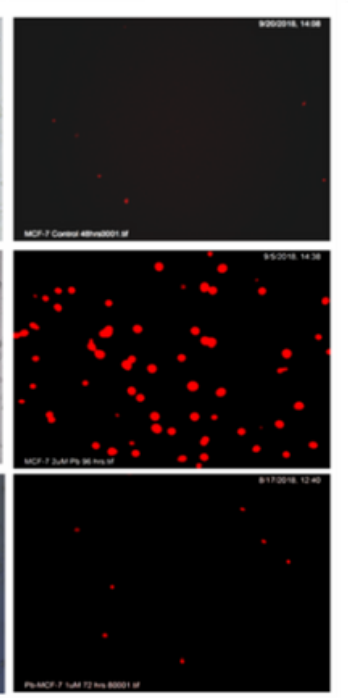

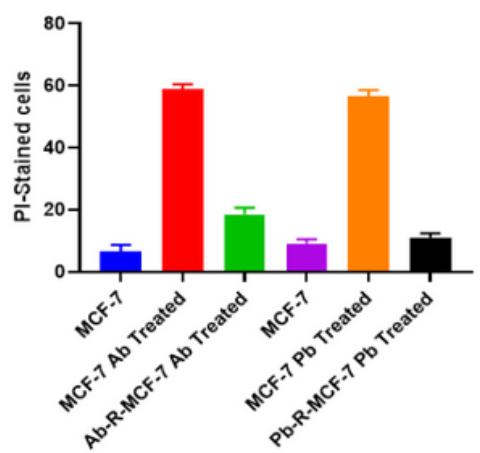

\section{Figure 1}

Cell-viability assay: (A) Ab-resistant and sensitive MCF-7 cells treated with Ab for 48 hrs. (B) Pb-resistant and sensitive MCF-7 cells treated with Pb for 72 hrs. PI-Staining and microscopy at 20x magnification: (C) MCF-7 control, MCF-7 Ab treated, and Ab-R-MCF-7 Ab treated for 48 hrs (D) MCF-7 control, MCF-7 Pb treated, and Pb-R-MCF-7 cells Pb treated for 72 hrs (E) Cells picked-up PI-stain in C and D samples. 
A

RQ of Genes
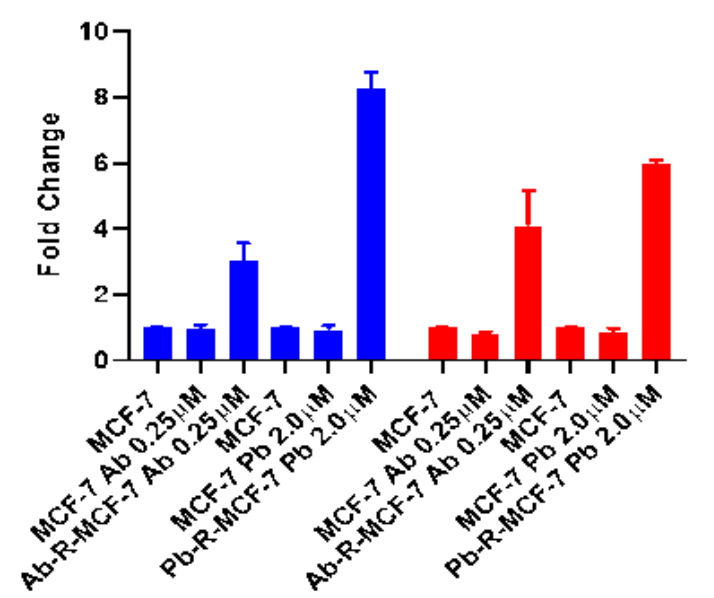

C
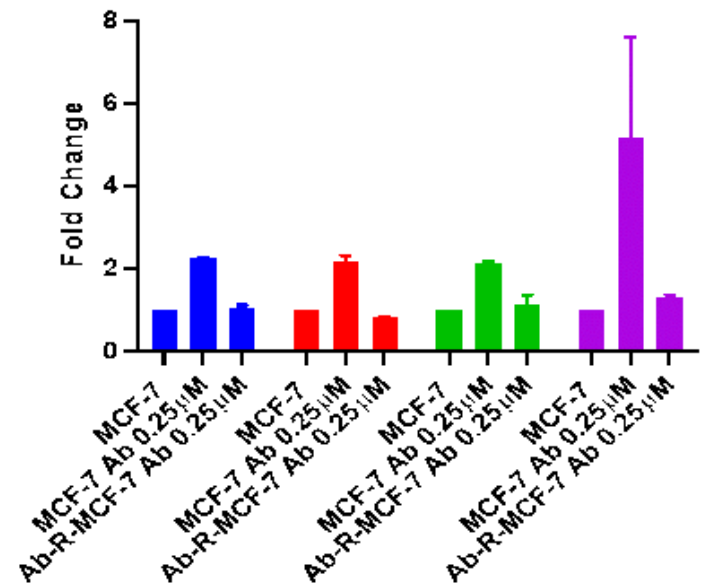

E
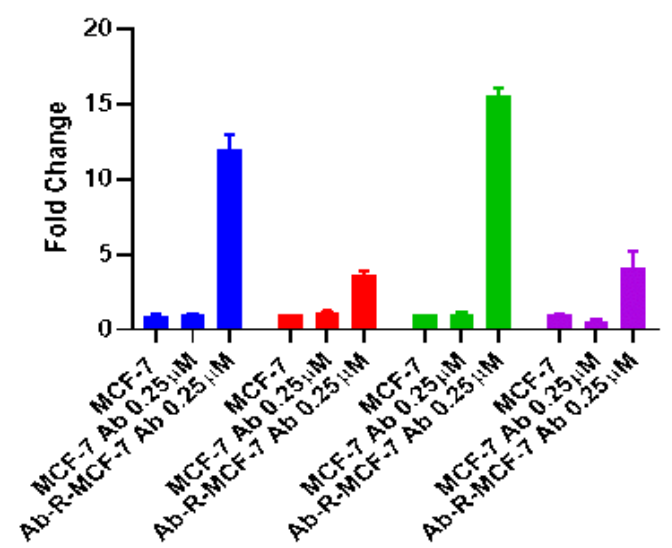

B

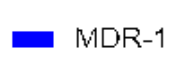

- AlBCO'

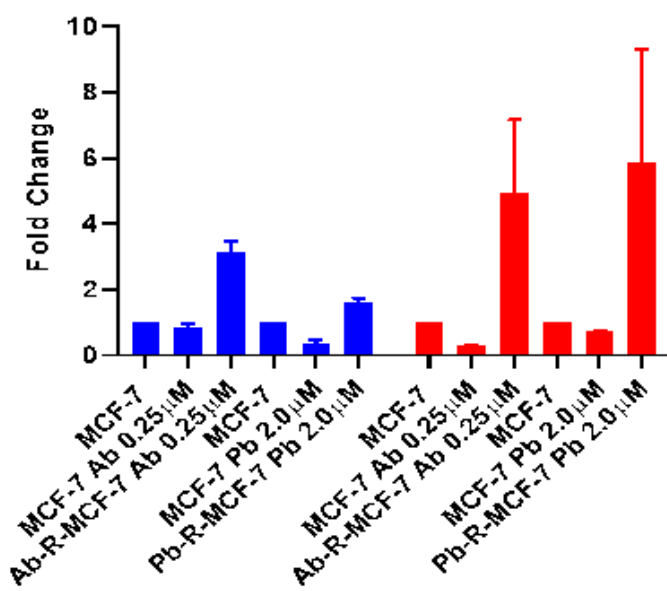

D

RQ of Genes

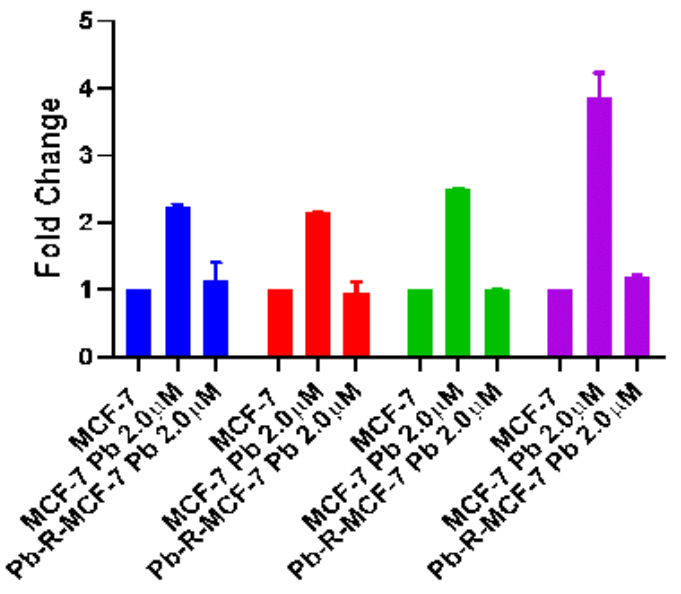

F

$R Q$ of Genes

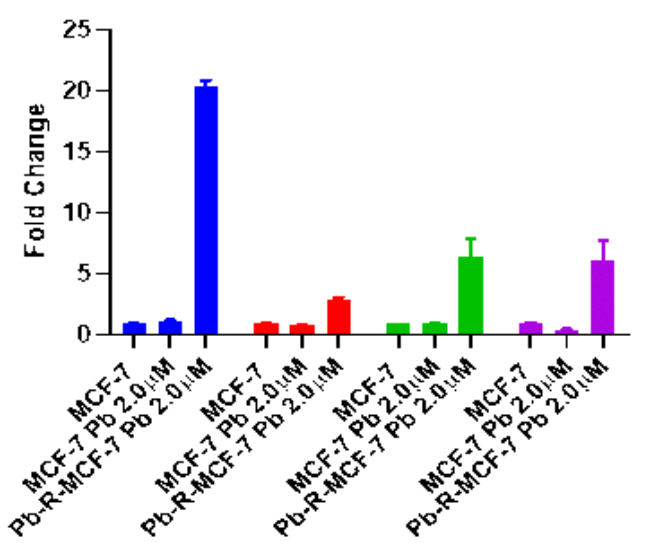

- ESR-1

- CDK-4

- COKE

- CYCLIND1

\section{Figure 2}

mRNA expression by real-time-qPCR. (A) MDR-1 and ABCG-2 genes expression in MCF-7 control, MCF-7 $\mathrm{Ab}$ or Pb treated and Ab-R-MCF-7 Ab or Pb treated. (B) BCL-2 and MCL-1 expression in MCF-7 control, MCF-7 Ab or Pb treated and Ab-R-MCF-7 Ab or Pb treated, (C) BAX, BAD, CASP-3 and PARP1 expression in MCF-7 control, MCF-7 Ab treated and Ab-R-MCF-7 Ab treated (D) BAX, BAD, CASP-3 and PARP1 expression in MCF-7 control, MCF-7 Pb treated and Pb-R-MCF-7 Pb treated (E) ESR-1, CDK-4, CDK-6 and CYCLIN D1 
expressions in MCF-7 control, MCF-7 Ab treated and Ab-R-MCF-7 Ab treated and (F) ESR-1, CDK-4, CDK-6 and CYCLIN D1 expressions in MCF-7 control, MCF-7 Pb treated and Pb-R-MCF-7 Pb treated.

A

Ab-R-MCF-7 Vs MCF-7 Control Proteome data

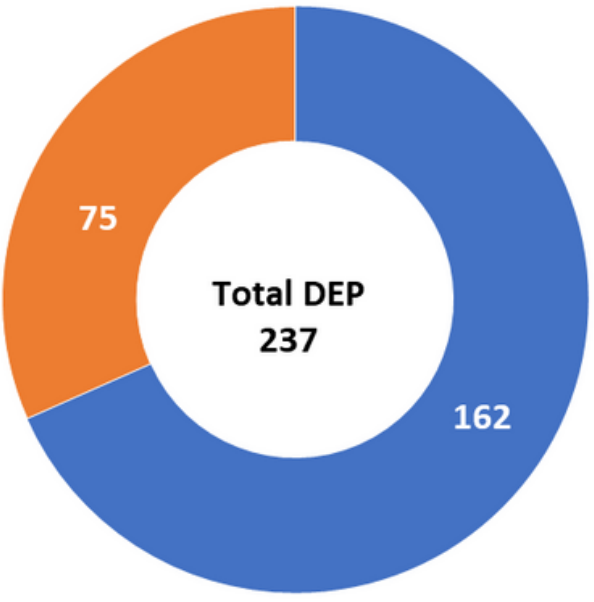

nown-Regulated $\quad$ Up-regulated

C

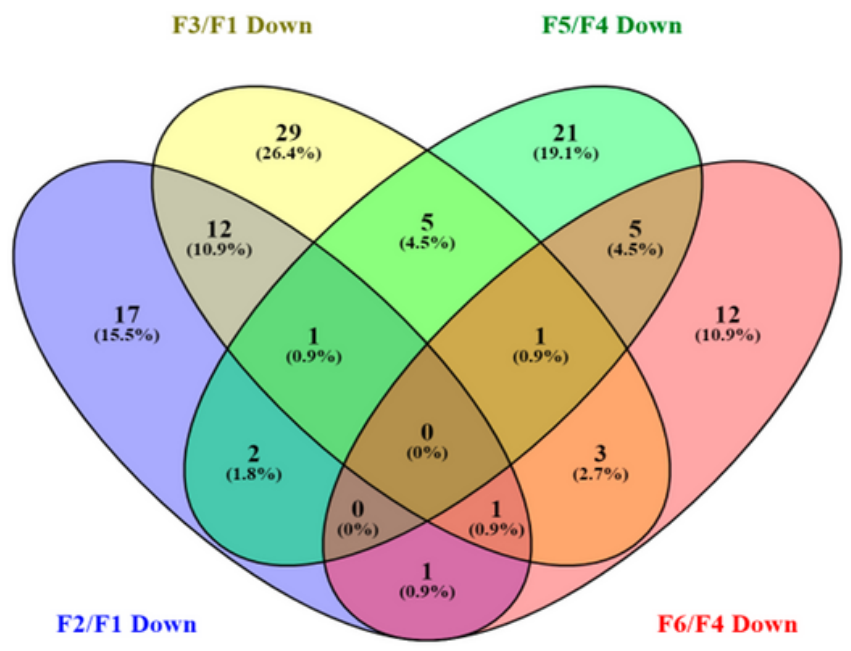

B Pb-R-MCF-7 vs MCF-7 Control Proteome data

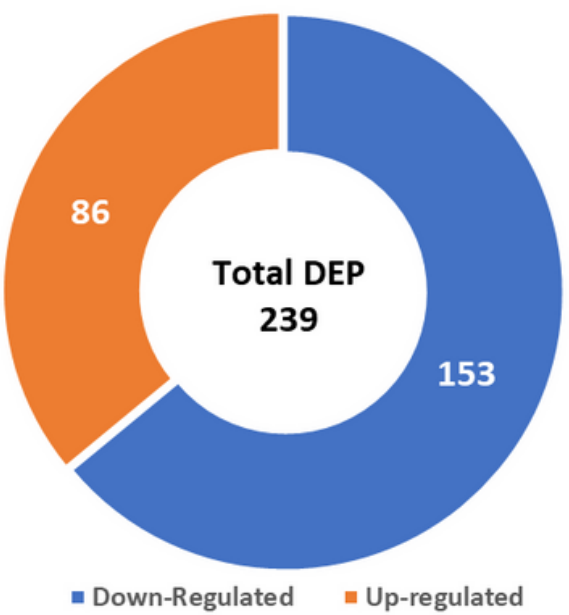

D $\quad$ F3/F1 Up

F5/F4 Up

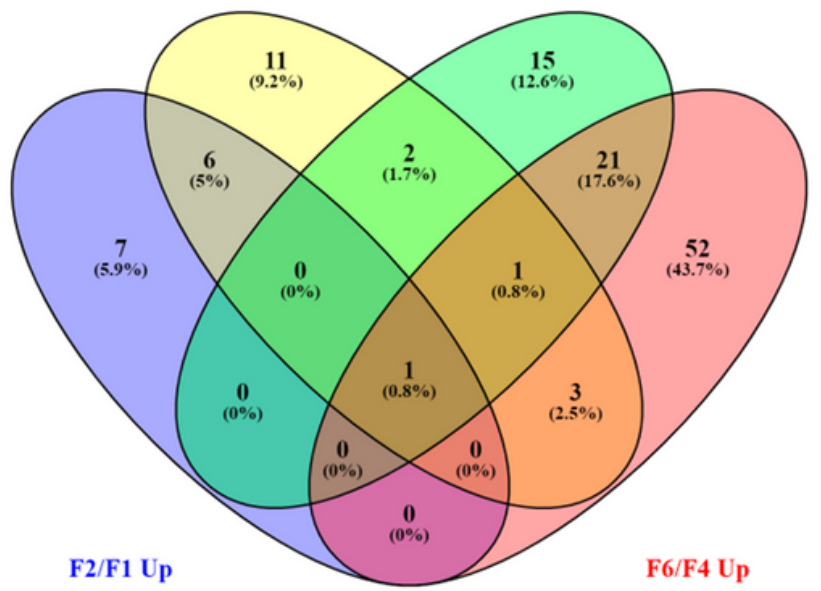

Figure 3

Differential expression of proteins. (A) Ab-R-MCF-7 vs MCF-7 control and (B) Pb-R-MCF-7 vs MCF-7 control. Venn-diagram of two set of differentially expressed proteins Ab-R-MCF-7 Vs control (F2/F1 and F5/F4) and Pb-R-MCF-7 Vs MCF-7 control (F3/F1 and F6/F4) in (C) down-regulated and (D) up-regulated proteins. 


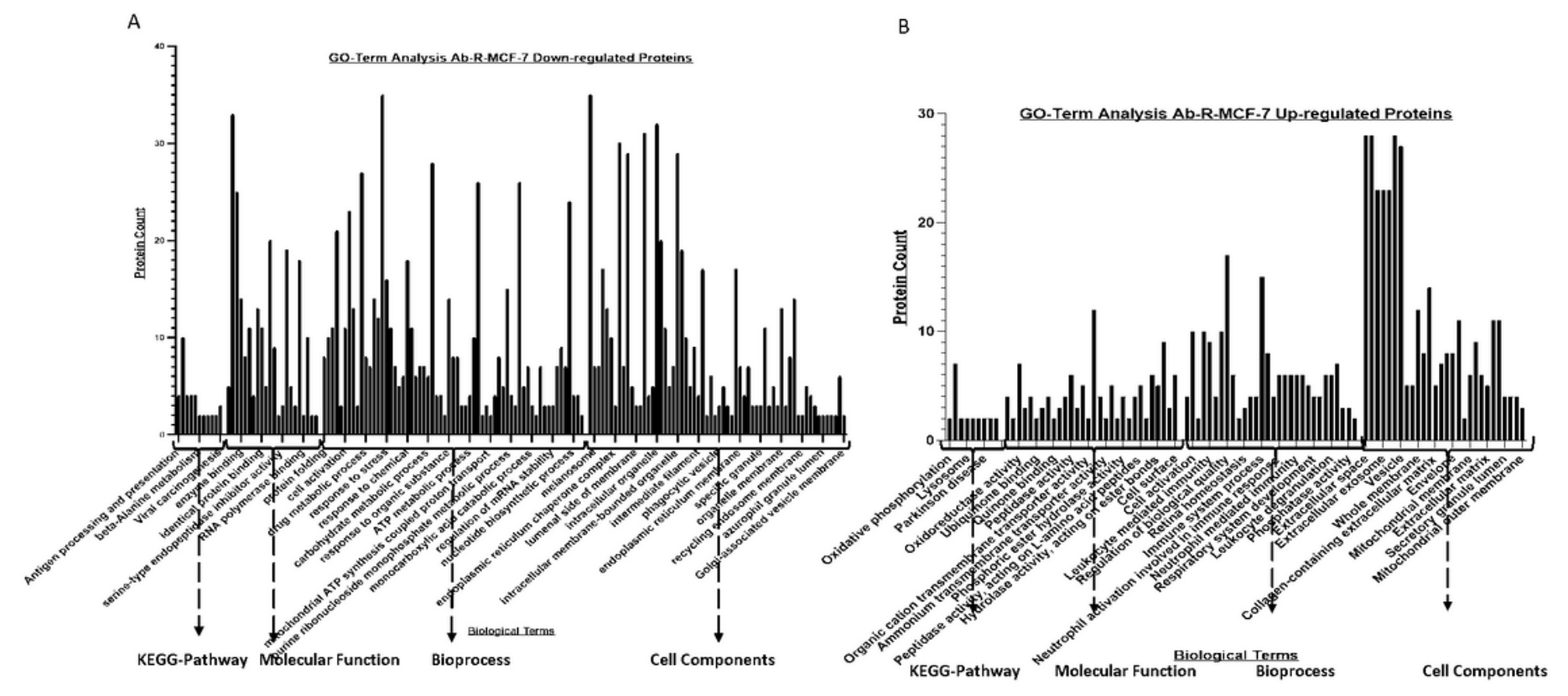

Figure 4

KEGG pathway and GO term analysis of differentially expressed proteins in Ab-R-MCF-7 cells compare to MCF-7 control cells (A) Down-regulated protein and (B) Up-regulated protein.
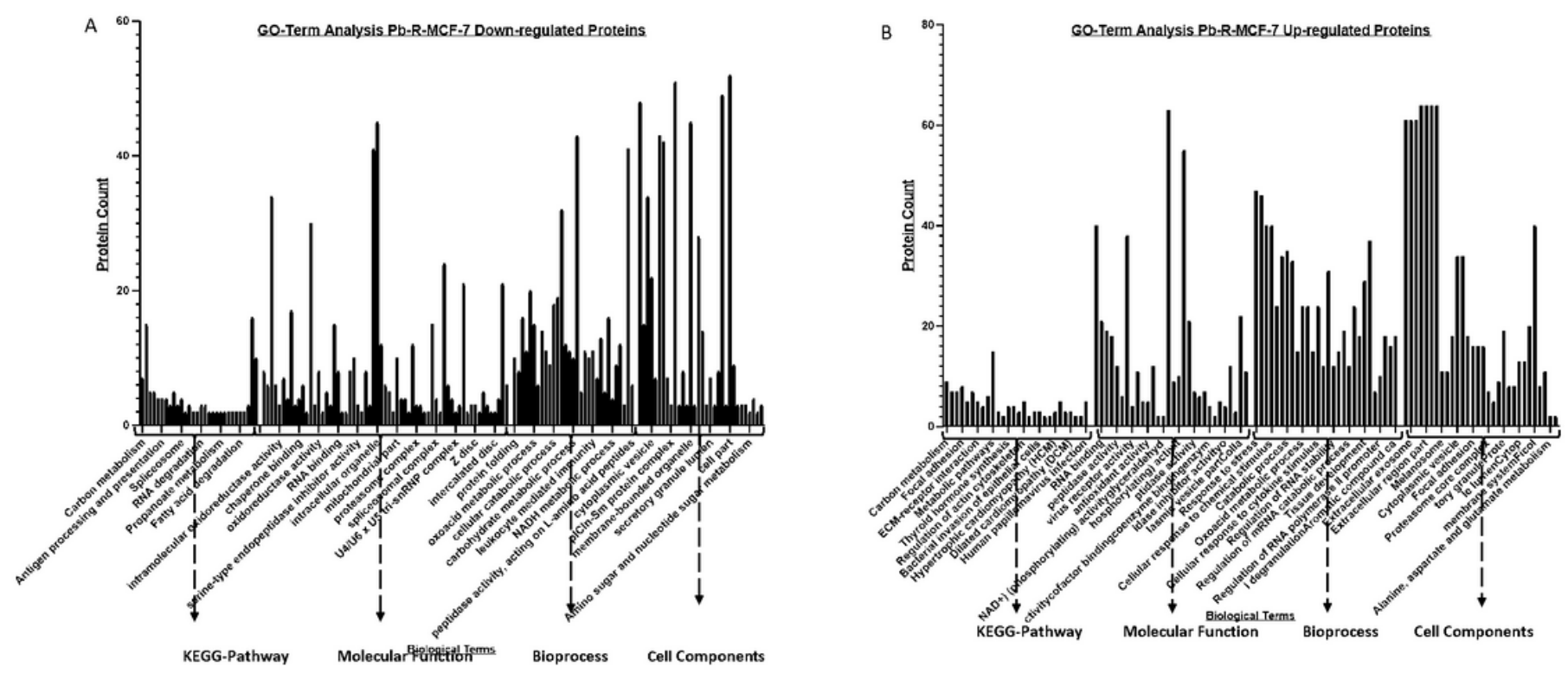

Figure 5

KEGG pathway and GO term analysis of differentially expressed proteins in Pb-R-MCF-7 cells compare to MCF-7 control cells (A) Down-regulated proteins and (B) Up-regulated proteins. 

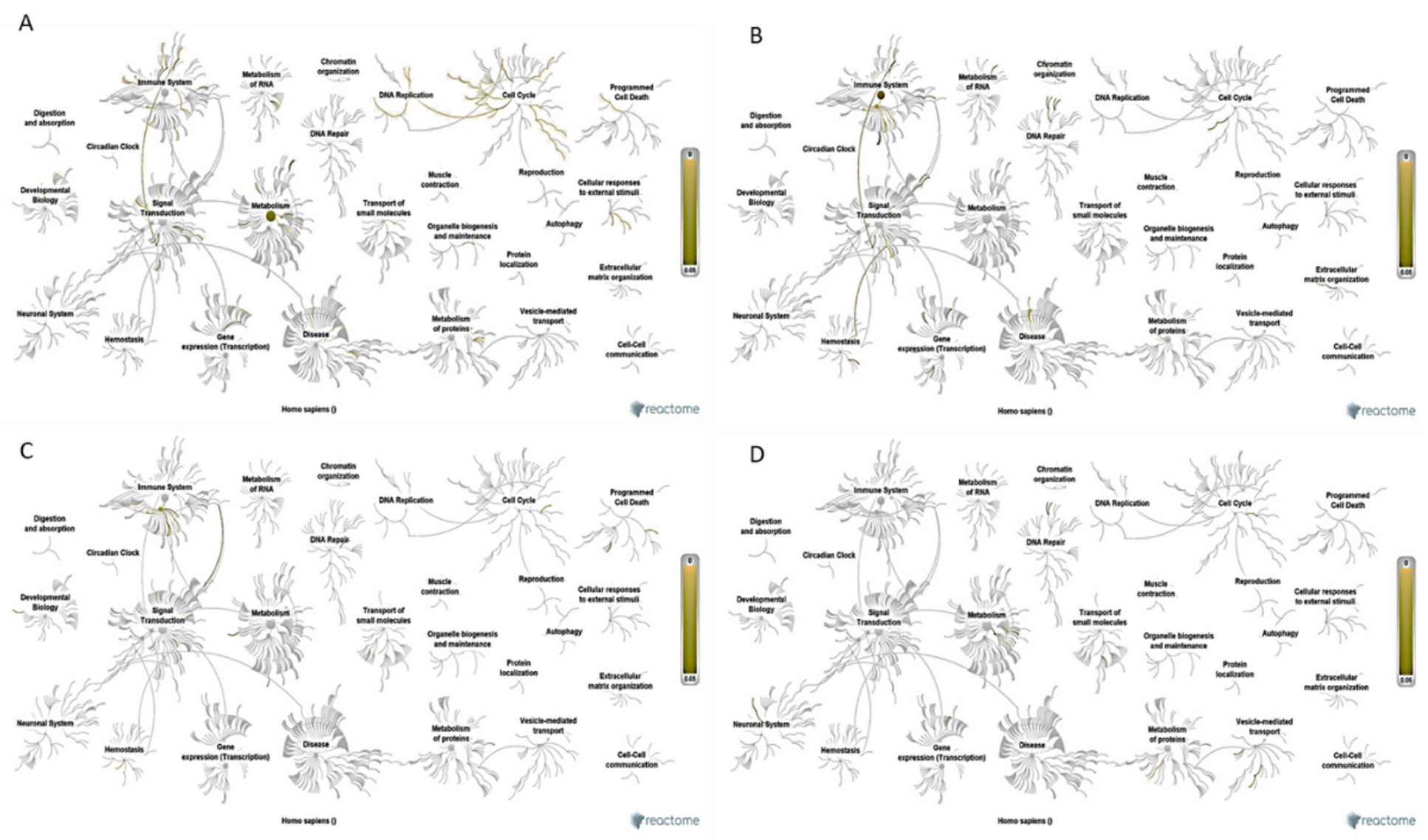

Figure 6

Reactome pathway analysis of differentially expressed proteins. (A) Common down-regulated Proteins in Ab-R-MCF-7/MCF-7 control in Set1 and Set 2 (Cut off 0.89), (B) Common up-regulated Proteins in Ab-RMCF-7/MCF-7 control in Set1 and Set 2 (Cut off 1.3) (C) Common Protein down-regulated in Ab-R-MCF7/MCF-7 control (Cut off 0.89) and (D) Common proteins up-regulated in Ab-R-MCF-7/MCF-7 control (Cut off 1.3). 


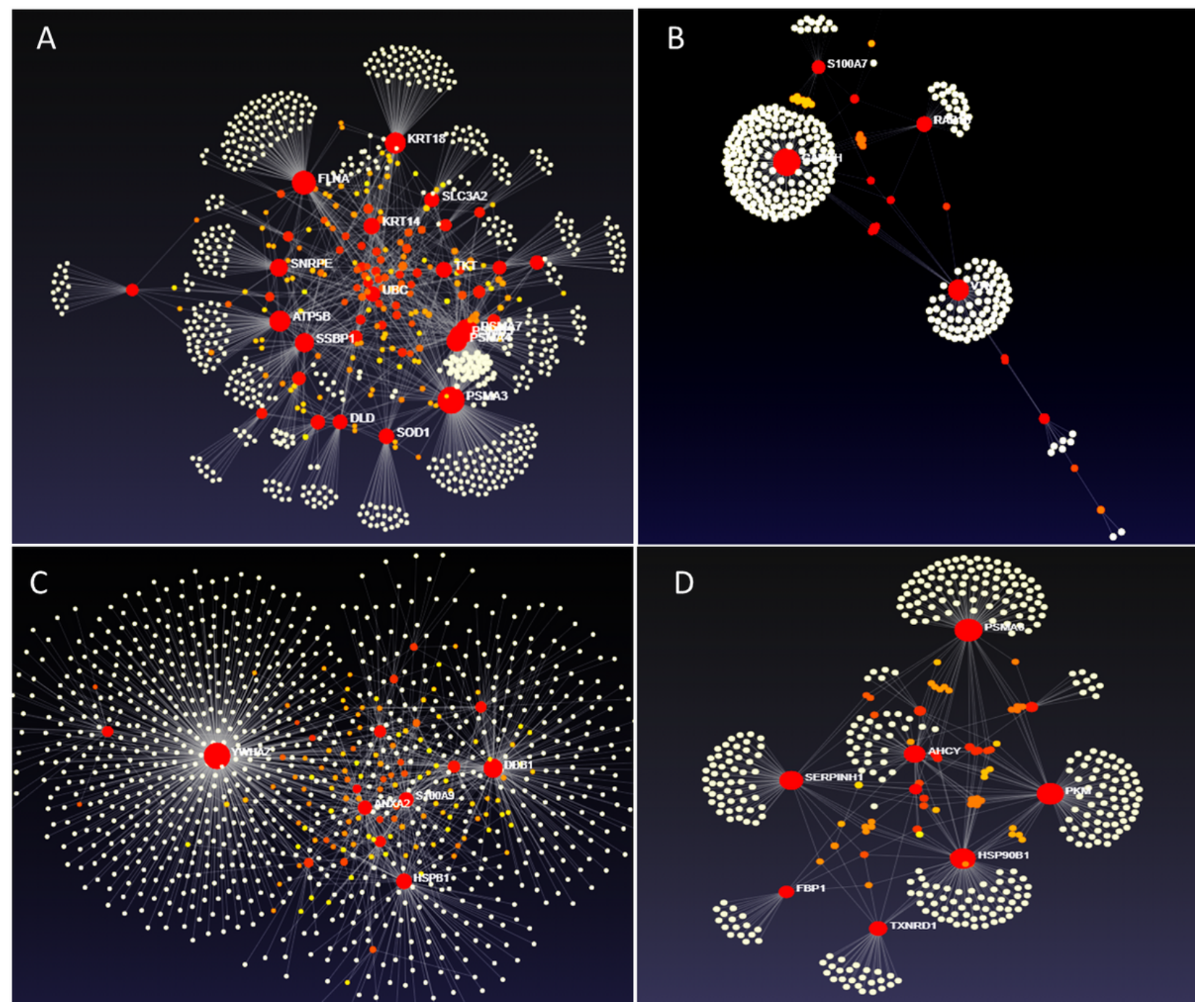

\section{Figure 7}

PPI-Network analysis (A) Common down-regulated Proteins in Ab-R-MCF-7/ MCF-7 control in Set1 and Set 2 (Cut off 0.89) (B) ) Common up-regulated Proteins in Ab-R-MCF-7/MCF-7 control in Set1 and Set 2 (Cut off 0.89) Interaction study (C) Common Protein down-regulated in Ab-R-MCF-7/MCF-7 control and (D) Common proteins up-regulated in Ab-R-MCF-7/MCF-7 control (Cut off 1.3). 

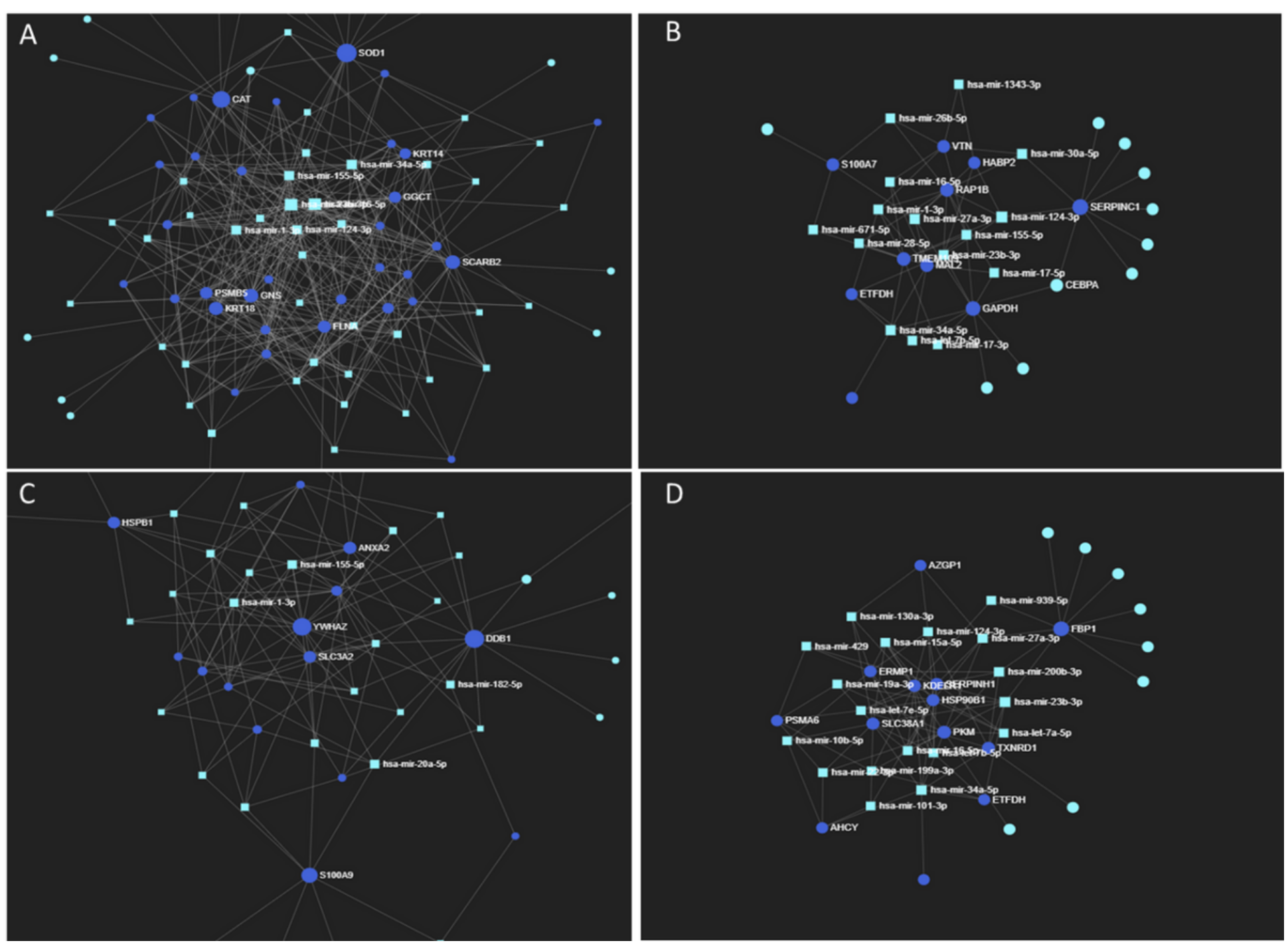

\section{Figure 8}

Common proteins and miRNA Minimum-network for differentially expressed common proteins in two biological set of experiment and their known miRNAs which target mRNA coding for the respective protein. (A) down-regulated proteins in Ab-R-MCF-7/MCF-7 control (F2/F1 and F5/F4) (Cut off 0.89), (B) up-regulated proteins in Ab-R-MCF-7/MCF-7 control (F2/F1 and F5/F4), (Cut off 1.3), (C) down-regulated proteins in Pb-R-MCF-7/MCF-7 control (F3/F1 and F6/F4) and (D) up-regulated protein in Pb-R-MCF7/MCF-7 control (F3/F1 and F6/F4) (Cut off 1.3).

\section{Supplementary Files}

This is a list of supplementary files associated with this preprint. Click to download.

- SupplimentaryTable1.docx

- SupplimentaryTable2.docx

- SupplimentaryTable3.docx 
- SupplimentaryTable4.docx

- SupplimentaryTable5.docx 